\title{
Article
}

\section{Neophyllachora gen nov. (Phyllachorales), three new species of Phyllachora from Poaceae and resurrection of Polystigmataceae (Xylariales)}

\section{Dayarathne $\mathrm{MC}^{1,2,3}$, Maharachchikumbura $\mathrm{SSN}^{4}$, Jones $\mathrm{EBG}^{6}$, Goonasekara $\mathrm{ID}^{1,2,3}$, Bulgakov $\mathrm{TS}^{5}$, Al-Sadi $\mathrm{AM}^{4}$, Hyde $\mathrm{KD}^{1,2,3,6}$, Lumyong $\mathrm{S}^{6}$ and McKenzie $\mathrm{EHC}^{6,7^{*}}$}

${ }^{1}$ Center of Excellence in Fungal Research, Mae Fah Luang University, Chiang Rai 57100, Thailand.

${ }^{2}$ World Agroforestry Centre East and Central Asia Office, 132 Lanhei Road, Kunming 650201, China.

${ }^{3}$ Key Laboratory for Plant Biodiversity and Biogeography of East Asia (KLPB), Kunming Institute of Botany, Chinese Academy of Science, Kunming 650201, Yunnan, China.

${ }^{4}$ Department of Crop Sciences, College of Agricultural and Marine Sciences, Sultan Qaboos University, PO Box 8,123 Al Khoud, Oman.

${ }^{5}$ Russian Research Institute of Floriculture and Subtropical Crops, 2/28 Yana Fabritsiusa Street, Sochi 354002, Krasnodar region, Russia

${ }^{6}$ Department of Biology, Faculty of Science, Chiang Mai University, Chiang Mai 50200, Thailand.

${ }^{7}$ Landcare Research New Zealand, Private Bag 92170, Auckland Mail Centre, Auckland 1142, New Zealand

Dayarathne MC, Maharachchikumbura SSN, Jones EBG, Goonasekara ID, Bulgakov TS, Al-Sadi AM, Hyde KD, Lumyong S, McKenzie EHC 2017 - Neophyllachora gen nov. (Phyllachorales), three new species of Phyllachora from Poaceae and resurrection of Polystigmataceae (Xylariales). Mycosphere 8(10), 1598-1625, Doi 10.5943/mycosphere/8/10/2

\begin{abstract}
We collected six "tar spot" disease specimens from various hosts and these were subjected to morpho-phylogenetic studies. In this paper, a new genus, Neophyllachora is introduced to accommodate $N$. cerradensis, $N$. myrciae, $N$. myrciariae, $N$. subcircinans and $N$. trucantispora, which are related to Phyllachora species but constitutes an independent strongly supported monophyletic clade within Phyllachoraceae of the Phyllachorales. Three novel Phyllachora species; P. chloridis, P. cynodonticola and $P$. panicicola on Poaceae are also introduced. Phenotypic comparisons and phylogenetic analysis of partial SSU, LSU and ITS sequence data with homologous taxa, confirm the placement of the novel species in Phyllachoraceae. The family Polystigmataceae is re-established to accommodate Polystigma within the order Xylariales. The asexual morph of Polystigma rubrum was re-collected from Russia and is provided as a reference specimen with a description, illustrations and molecular data. Further studies with multiple gene analysis are recommended to provide a natural and stable classification system for members of Phyllachorales.
\end{abstract}

Key words - biotrophs - phylogeny - tar spots - taxonomy

Submitted 12 October 2017, Accepted 14 October 2017, Published 8 November 2017

Corresponding Author: - Lumyong S and McKenzie EHC - e-mail - scboi009@gmail.com,

mckenziee@landcareresearch.co.nz 


\section{Introduction}

Members of the family Phyllachoraceae are obligate biotrophs known to be minor pathogens, and facilitate a pathway for secondary infection by other more severe pathogenic organisms (Pearce et al. 1999). Phyllachoraceae was introduced by Theissen \& Sydow (1915) and referred to different orders, including Dothideales (Horst 1990), Sphaeriales (Nannfeldt 1932, Miller 1949, Muller \& Arx 1962, Wehmeyer 1975), Xylariales (Luttrell 1951, Barr 1990), Glomerellales (Chadefaud 1960, Locquin 1984), Phyllachorales (Barr 1976a, b, 1983), Polystigmatales (Eriksson 1982, Hawksworth et al. 1983) and Diaporthales (Cannon 1988). Maharachchikumbura et al. (2016) placed the order Phyllachorales with two families, Phaeochoraceae and Phyllachoraceae, in the subclass Sordariomycetidae and this was confirmed by later studies (Maharachchikumbura et al. 2016, Hongsanan et al. 2017). A recent study by Mardones et al. (2017) proposed a new family Telimenaceae with Telimena erythrinae as the type species, resulting in three families in the Phyllachorales. The number of recognized genera within this diverse family varies according to the authority. Hawksworth (1985) recognized 23 genera, whereas Barr (1990) provided a key to genera in Phyllachoraceae, including only 12 genera. Eriksson \& Hawksworth (1993) recognized 39 genera; Hawksworth et al. (1995) accepted 42 genera, while Pearce \& Hyde (2001) introdued a novel genus Parberya. Phyllachoraceae currently comprises 59 genera (Maharachchikumbura et al. 2016, Mardones et al. 2017) which are believed to have evolved at approximately 217 MYA (Hongsanan et al. 2017). Species of Phyllachoraceae have been documented from a variety of plant host families (Pearce \& Hyde 1993, Cannon 1997, Pearce et al. 2000, 2001) and most taxa have been presumed to be hostspecific (Pearce et al. 1999). Members of Phyllachoraceae can be recognized by ascohymenial development with paraphyses, thin-walled asci, which might have an apical ring and ascospores that are often hyaline and 1-celled (Cannon 1991, Maharachchikumbura et al. 2016). The asexual morphs of Phyllachoraceae are coelomycetes, spermatial or disseminative (Hawksworth et al. 1995).

The genus Phyllachora was introduced based on a herbarium label in Fuckels exsiccate series 'Fungi Rhenani' with a single species, P. agrostis (Fuckel 1867 in Cannon 1991), synonymized as Scirrhia agrostis in Dothideales (Eriksson 1967). Later, Phyllachora was lectotypified with $P$. graminis [Pers.] Fuckel) as generic type (Clements \& Shear 1931). Currently Phyllachora is recognized as the largest genus in this family with about 1500 species epithets (Maharachchikumbura et al. 2016, Index Fungorum 2017). It comprises species that grow immersed in a clypeate pseudostroma in leaf tissues, varying from a subcuticular or intra-epidermal, to a generalized infection of the entire section of the mesophyll, inducing characteristic black shiny superficial symptoms, commonly known as tar spots (Santos et al. 2016). A large number of Phyllachora species have been given names based on host association and this may not reflect the actual number of species (Cannon 1988). There have been several morphological studies of Phyllachora on various groups of host plants. For example, leaf-spots on grasses and sedges in northern regions (Seaver 1928), Phyllachora species causing tar spot on Leguminosae (Cannon 1991), Duranta spp. in the tropics (Hanlin \& Tortolero 1991), small scabby leaf spots or "lixa-pequena" on coconut palms in Brazil (Subileau et al. 1993), leaf-spots on the plant family Asclepiadaceae (Pearce et al. 1999), phyllachoraceous species from Arecaceae (Hyde \& Cannon 1999), Phyllachora shiraiana complex from Bambusa arnhemica (Pearce et al. 2000), Phyllachoraceae species on hosts in the family Proteaceae and tar spots on grasses in Australia (Sivanesan \& Shivas 2002) and Phyllachora thysanolaenae on Thysanolaena maxima and Phyllachora vetiveriana on Chysopogon zizanioides in Thailand (Tamakaew et al. 2017). However, most of these studies are based on morphological data. There is still some taxonomic confusion with the taxonomy of Phyllachora given that species have been reported to be polyphyletic (Santos et al. (2016).

Polystigma is a biotrophic genus aslo included at times in Phyllachoraceae, which causes reddish-brown or purple leaf spots on living leaves mostly on Prunus species. Accurate morphological identification of the species that cause these diseases remains uncertain, but is thought to be a close 
relative of Phyllachora, as only a few distinguishing characters remain between the two genera apart from stromatal pigmentation (Cannon 1996). Polystigma asexual morphs have conidiogenous cells, which proliferate sympodially, rather than percurrently, which is a common characteristic of asexual morphs of Phyllachoraceae (Cannon 1996, Habibi et al. 2015). The type, Polystigma rubrum is characterized by typically swollen, red/orange/brown (not purple) stromata, bordered by apparently healthy leaf tissues that produce distinctive hooked or curved conidia (http://fungi.myspecies.info/content/lost-found-fungi-project, 2015). Historically this species was documented from 30 counties in Great Britain and Ireland, found abundantly along the east and west coasts of England and Wales (http://fungi.myspecies.info/content/lost-found-fungi-project, 2015). Farr \& Rossman (2016) recorded this species as widely distributed throughout the world. In a study by Habibi et al. (2015) Po. amygdalinum and Po. rubrum grouped in Xylariomycetidae and in Mardones et al. (2017) Po. pusillum and Polystigma sp. clustered with Phyllachora species, while other Polystigma species did not group among other phyllachoraceous taxa, but with Trichosphaeriales and Xylariales in the Xylariomycetidae.

The aim of this study is a morpho-molecular evaluation of 30 spots of six "tar spot" disease specimens collected in China and Thailand. We introduce a novel genus, Neophyllachora, in Phyllachoraceae, to accomodate some Phyllachora taxa which are phylogenetically distinct from the type species. Three novel species of Phyllachora are introduced along with a re-assessment of Phyllchoraceae species. Polystigmataceae is re-established with descriptions, illustrations and molecular data from Po. rubrum which groups within the order Xylariales.

\section{Materials and Methods}

\section{Sample collections and examination}

Fresh materials were collected from China, Russia and Thailand during January 2015 to December 2016. Samples were examined with a Motic SMZ 168 stereomicroscope. Micromorphological characters of taxa were observed and images were captured under a Nikon ECLIPSE 80i compound microscope with a Canon EOS 550D digital camera. Observations and photographs were made from squash mounts of fresh fruiting bodies mounted in water and stained with Melzer's reagent. Measurements were taken with the Tarosoft $(\mathrm{R})$ Image Frame Work. Adobe Photoshop CS5 version 10.0 software was used to prepare the Fig.s. Herbarium specimens were deposited in the Mae Fah Luang University Herbarium (MFLU) and Herbarium of Cryptogams Kunming Institute of Botany Academia Sinica (KUN-HKAS). Faces of fungi and Index Fungorum numbers were registered according to Jayasiri et al. (2015), Index Fungorum (2017). New species are established based on recommendations outlined by Jeewon \& Hyde (2016).

\section{DNA extraction, PCR amplification and sequencing}

Genomic DNA was extracted from fruiting bodies using an E.Z.N.A. ${ }^{\circledR}$ Forensic DNA kit (D3591- 01, Omega Bio-Tek) following the manufacturer's protocol. DNA amplification was performed by polymerase chain reaction (PCR). The partial large subunit nuclear rDNA (28S, LSU) was amplified with primer pair LROR and LR5 (Vilgalys \& Hester 1990). Primer pair NS1 and NS4 was used to amplify the partial small subunit nuclear rDNA (18S, SSU) (White et al. 1990) and the primer pair ITS5 and ITS4 was used to amplify the internal transcribed spacer regions (ITS) (White et

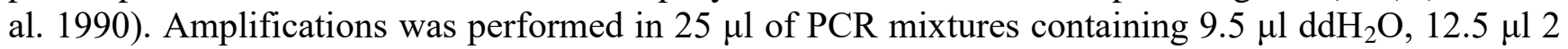
$\times$ PCR Master Mix, $1 \mu \mathrm{l}$ of DNA template and $1 \mu \mathrm{l}$ of each primer $(10 \mu \mathrm{M})$. The PCR thermal cycle program was an initial step of 3 mins at $94^{\circ} \mathrm{C}$, followed by 35 cycles of $30 \mathrm{sec}$ at $94^{\circ} \mathrm{C}, 58 \mathrm{sec}$ at $30^{\circ} \mathrm{C}$, and $1 \mathrm{~min}$ at $72^{\circ} \mathrm{C}$, with a final extension of $10 \mathrm{mins}$ at $72^{\circ} \mathrm{C}$. The PCR products were observed on $1 \%$ agarose electrophoresis gels stained with $4 \mathrm{~S}$ green stain. 


\section{Phylogenetic analysis}

Table 1 GenBank and culture collection accession numbers of isolates included in this study. Sequences generated in this study are in blue.

\begin{tabular}{|c|c|c|c|c|}
\hline \multirow[b]{2}{*}{ Taxon } & \multirow[b]{2}{*}{ Strain } & \multicolumn{3}{|c|}{ GenBank Accessions } \\
\hline & & LSU & SSU & ITS \\
\hline Achaetomium strumarium & IMI 082624 & AJ312098 & - & - \\
\hline Albertiniella polyporicola & NBRC 30914 & $\mathrm{AB} 178271$ & - & AB278196 \\
\hline Ambrosiella ferruginea & CBS 46082 & EU825651 & KR673890 & KC305146 \\
\hline Amphisphaeria umbrina & HKUCC 994 & AF452029 & AY083811 & - \\
\hline Amplistroma caroliniana & BEO9923 & FJ532377 & - & - \\
\hline Amplistroma erinaceum & AH 43902 & KC907374 & - & NR145379 \\
\hline Amplistroma longicollis & AH37870 & HQ901790 & - & - \\
\hline Annulatascus velatisporus & HKUCC 3701 & AF132320 & - & - \\
\hline Annulusmagnus triseptatus & CBS 128831 & GQ996540 & JQ429242 & - \\
\hline Apiorhynchostoma curreyi & UAMH 11088 & NG042715 & - & NR120207 \\
\hline Apiospora montagnei & AFTOL-ID 951 & DQ471018 & FJ190614 & - \\
\hline Arachnocrea stipata & TFC 97-43 & AF160227 & - & - \\
\hline Arthrinium phaeospermum & HKUCC 3395 & AY083832 & AY083816 & - \\
\hline Ascitendus austriacus & MR 2936 & GQ996539 & GQ996542 & - \\
\hline Ascothailandia grenadoidia & NB 2010a & GQ390267 & GQ390252 & GQ390282 \\
\hline Ascovaginospora stellipala & P5-13A & ASU85088 & - & - \\
\hline Australiasca queenslandica & BRIP 24607 & HM237324 & - & HM237327 \\
\hline Bartalinia robillardoides & CBS 122705 & KJ710438 & - & NR126145 \\
\hline Beltrania pseudorhombica & СРC 23656 & KJ869215 & - & KJ869158 \\
\hline Bionectria ochroleuca & AFTOL-ID 187 & DQ862027 & DQ862044 & - \\
\hline Bisconiauxi anummularia & MUCL51395 & KT281894 & - & KY610382 \\
\hline Bombardia bombarda & AFTOL-ID 967 & DQ470970 & - & DQ471021 \\
\hline Cainia graminis & CBS 136.62 & AF431949 & AF431952 & - \\
\hline Calosphaeria pulchella & JF 03200 & AY761075 & AY761071 & - \\
\hline Camarotella costaricensis & MM-149 & KX430484 & KX451863 & KX451913 \\
\hline Camarotella costaricensis & MM-21 & KX430490 & KX451851 & KX451900 \\
\hline Camarotella sp. & MM-27 & KX430492 & KX451852 & KX451901 \\
\hline Canalisporium caribense & SS038397 & GQ390269 & GQ390253 & GQ390284 \\
\hline Carpoligna pleurothecii & CBS 101580 & GU017318 & JQ429247 & JQ429147 \\
\hline Catabotrys deciduum & SMH3436 & AY346268 & - & - \\
\hline Cephalotheca foveolata & UAMH11631 & KC408398 & - & KC408422 \\
\hline Chaetomidium galaicum & CBS 113678 & FJ666361 & - & - \\
\hline Chaetosphaerella fusca & GKML124N & FJ968967 & - & - \\
\hline Claviceps purpurea & AEG 972 & AF543789 & AF543765 & - \\
\hline Clypeosphaeria uniseptata & HKUCC 6349 & AY083830 & DQ810255 & - \\
\hline Coccodiella melastomatum & 54964 & - & CMU78543 & - \\
\hline Coccodiella melastomatum & CMU78543 & - & U78543 & - \\
\hline & PMAPAN M & & & - \\
\hline Coccodiella miconiae & 0141106 & - & GU233440 & \\
\hline Coccodiella miconiae & MP1342 & KX430506 & KX451871 & - \\
\hline
\end{tabular}


Table 1 Continued.

\begin{tabular}{|c|c|c|c|c|}
\hline \multirow[b]{2}{*}{ Taxon } & \multirow[b]{2}{*}{ Strain } & \multicolumn{3}{|c|}{ GenBank Accessions } \\
\hline & & LSU & SSU & ITS \\
\hline Coccodiella miconiicola & TH571 & KX430512 & KX451880 & - \\
\hline Coccodiella sp. & MM-165 & KX430488 & KX451865 & KX451917 \\
\hline Coccodiella toledoi & Unknown & - & U78544 & - \\
\hline Cocoicola californica & F59034 & KX430468 & KX451866 & KX451918 \\
\hline Cocoicola californica & F59038 & KX430469 & KX451867 & KX451919 \\
\hline Colletotrichum gloeosporioides & LC0555 & JN940412 & JN940356 & JN943090 \\
\hline Coniocessia maxima & Co117 & GU553344 & - & NR137751 \\
\hline Coniocessia nodulisporioides & CBS 281.77 & AJ875224 & AJ875185 & - \\
\hline Coniochaeta ligniaria & $\mathrm{C} 8$ & AY198388 & AY198389 & AY198390 \\
\hline Conioscypha lignicola & CBS 335.93 & AY484513 & JQ437440 & - \\
\hline Copromyces sp. & CBS 386.78 & AY346277 & DQ471007 & - \\
\hline Cordana abramovii & PE 0053-24a & KF833358 & - & - \\
\hline Cordana inaequalis & CBS 508.83 & HE672157 & - & NR145363 \\
\hline Cordana mercadiana & FMR:11828 & HE672165 & - & HE672154 \\
\hline Cordana pauciseptata & CBS 121804 & HE672160 & - & HE672149 \\
\hline Cordyceps cardinalis & OSC 93609 & AY184962 & AY184973 & - \\
\hline Cryptadelphia groenendalensis & SMH3767 & EU528001 & - & - \\
\hline Cryptendoxyla hypophloia & WM10 89 & HQ014708 & - & - \\
\hline Diatrype disciformis & AFTOLID 927 & DQ470964 & DQ471012 & \\
\hline Diatrype whitmanensis & ATCC MYA-4417 & FJ430587 & - & - \\
\hline Discostroma sp. & HKUCC 1004 & AF382380 & AY083814 & - \\
\hline Dothidea sambuci & DAOM 231303 & NG027611 & NR111220 & AY883094 \\
\hline Duradens sp. & SMH1708 & AY780068 & AY761067 & - \\
\hline Endoxyla operculata & UAMH 11085 & NG042718 & - & NR120209 \\
\hline Etheirophora blepharospora & JK5397A & EF027723 & - & EF027717 \\
\hline $\begin{array}{l}\text { Exserticlava vasiformis } \\
\text { Falcocladium }\end{array}$ & TAMA 450 & AB753846 & - & - \\
\hline sphaeropedunculatum & CBS 111292 & JF831933 & JF831929 & JF831938 \\
\hline Falcocladium thailandicum & CBS 121717 & JF831934 & JF831930 & JF831939 \\
\hline Flammocladiella aceris & СРC 24422 & KR611901 & - & KR611883 \\
\hline Fragosphaeria purpurea & CBS 133.34 & AB189154 & AF096176 & AB278192 \\
\hline Gelasinospora tetrasperma & CBS 178.33 & - & - & NR077163 \\
\hline Gnomonia gnomon & CBS199.53 & AF408361 & - & - \\
\hline Gondwanamyces capensis & CMW 997 & KM495391 & - & EU660439 \\
\hline Graphostroma platystoma & AFTOL-ID 1249 & DQ836906 & DQ836900 & - \\
\hline Halosphaeria appendiculata & CBS 197.60 & HAU46885 & HAU46872 & - \\
\hline Hyponectria buxi & UME 31430 & AY083834 & AF130976 & - \\
\hline Iodosphaeria tongrenensis & MFLU 15-0393 & KR095283 & KR095284 & KR095282 \\
\hline Jattaea prunicola & STE-U 6201 & EU367456 & EU367462 & NR135946 \\
\hline Juncigena adarca & JK5235A & EF027726 & EF027719 & - \\
\hline Koralionastes ellipticus & JK5771 & EU863583 & EU863580 & - \\
\hline Koralionastes ellipticus & JK5769 & EU863585 & EU863581 & - \\
\hline Lasiosphaeria ovina & SMH4605 & AY436413 & - & AY587923. \\
\hline Lecythophora luteoviridis & CBS 20638 & FR691987 & - & DQ404354 \\
\hline
\end{tabular}


Table 1 Continued.

\begin{tabular}{|c|c|c|c|c|}
\hline \multirow[b]{2}{*}{ Taxon } & \multirow[b]{2}{*}{ Strain } & \multicolumn{3}{|c|}{ GenBank Accessions } \\
\hline & & LSU & SSU & ITS \\
\hline Lecythothecium duriligni & CBS 101317 & AF261071 & - & - \\
\hline Leucostoma niveum & AR3413 & AF362558 & - & - \\
\hline Lindra thalassiae & AFTOL-ID 413 & DQ470947 & DQ470994 & DQ491508 \\
\hline Lopadostoma turgidum & $\mathrm{LT} 2$ & - & - & KC774618 \\
\hline Lulworthia fucicola & ATCC 64288 & AY878965 & AY879007 & - \\
\hline Magnaporthe salvinii & M21 & JF414887 & JF414862 & JF414838 \\
\hline Melanochaeta hemipsila & SMH2125 & AY346292 & - & - \\
\hline Melogramma campylosporum & JF440978 & - & - & JF440978 \\
\hline Microascus trigonosporus & AFTOL-ID 914 & DQ470958 & DQ471006 & DQ491513 \\
\hline Microdochium phragmitis & CBS 423.78 & KP858948 & - & KP859012 \\
\hline Nectria cinnabarina & CBS 114055 & KU382228 & - & - \\
\hline Neophyllachora cerradensis & UB15626 & - & - & KC683454 \\
\hline Neophyllachora cerradensis & UB16014 & - & - & KC683455 \\
\hline Neophyllachora cerradensis & UB21823 & - & KC740651 & KC683470 \\
\hline Neophyllachora cerradensis & UB21908 & - & KC740623 & KC683471 \\
\hline Neophyllachora myrciae & UB21292 & - & KC902620 & KC683463 \\
\hline Neophyllachora myrciae & UB22192 & - & KC740631 & KC683476 \\
\hline Neophyllachora myrciariae & UB21781 & & & KC683469 \\
\hline Neophyllachora subcircinans & UB09748 & - & - & KC683441 \\
\hline Neophyllachora subcircinans & UB21238 & - & - & KC683461 \\
\hline Neophyllachora subcircinans & UB21347 & - & - & KC683466 \\
\hline Neophyllachora subcircinans & UB2 1747 & - & KC902622 & KC683467 \\
\hline Neophyllachora truncatispora & UB14083 & - & KC740652 & KC683448 \\
\hline Neurospora crassa & MUCL 19026 & AF286411 & - & - \\
\hline Niesslia exilis & CBS 357.70 & AY489718 & AY489686 & - \\
\hline Nitschkia tetraspora & GKML148N & FJ968987 & - & - \\
\hline Ophioceras dolichostomum & HKUCC 10113 & DQ341507 & DQ341485. & - \\
\hline Ophioceras dolichostomum & CBS 114926 & JX134689 & JX134663 & NR120171 \\
\hline Ophiocordyceps sinensis & YN09 64 & JX968033 & JX968028 & JQ325141 \\
\hline Ophiodiaporthe cyatheae & YMJ 1364 & JX570891 & JX570890 & JX570889 \\
\hline Ophiodothella vaccinii & ATCC 36333 & - & U78777 & - \\
\hline Ophiostoma stenoceras & AFTOL-ID 1038 & DQ836904 & DQ836897 & - \\
\hline $\begin{array}{l}\text { Parapleurotheciopsis } \\
\text { inaequiseptata }\end{array}$ & MUCL 4108 & EU040235 & - & EU040235 \\
\hline Pestalotiopsis theae & SAJ-0021 & JN940838 & JN940785 & JN943623 \\
\hline $\begin{array}{l}\text { Phaeoacremonium novae- } \\
\text { zealandiae } \\
\text { Phlogicylindrium }\end{array}$ & WIN 113BI & AY761081 & AY761069 & NR136064 \\
\hline eucalyptorum & CBS 111689 & KF251708 & - & KF251205 \\
\hline Phlogicylindrium uniforme & CBS 131312 & JQ044445 & - & JQ044426 \\
\hline Phyllachora chloridis & MFLU 15-0173 & MF197499 & MF197505 & KY594026 \\
\hline Phyllachora chloridis & MFLU 16-2980 & MF197500 & MF197506 & KY594027 \\
\hline Phyllachora chrysopagonii & MFUH $16-2096$ & MF372146 & - & MF372145 \\
\hline Phyllachora cynodonticola & MFLU 16-2978 & MF197502 & MF197508 & KY594025 \\
\hline Phyllachora cynodonticola & MFLU 16-2977 & MF197501 & MF197507 & KY594024 \\
\hline
\end{tabular}


Table 1 Continued.

\begin{tabular}{|c|c|c|c|c|}
\hline \multirow[b]{2}{*}{ Taxon } & \multirow[b]{2}{*}{ Strain } & \multicolumn{3}{|c|}{ GenBank Accessions } \\
\hline & & LSU & SSU & ITS \\
\hline Phyllachora graminis & 101486 & - & - & AF257111 \\
\hline Phyllachora graminis & DAOM 240981 & - & - & HQ317550 \\
\hline Phyllachora graminis & UME 31349 & - & AF064051 & - \\
\hline Phyllachora graminis & RoKi3084 & - & KX451872 & - \\
\hline Phyllachora graminis & MM-166 & - & KX451869 & KX451920 \\
\hline Phyllachora graminis & TH544 & $\mathrm{KX} 430508$ & KX451873 & - \\
\hline Phyllachora maydis & BPI 893231 & - & - & KU184459 \\
\hline Phyllachora panicicola & MFLU16-2979 & MF197503 & MF197504 & KY594028 \\
\hline Phyllachora qualeae & UB21145 & - & - & KT380955 \\
\hline Phyllachora qualeae & UB 21159 & & - & KU682781 \\
\hline Phyllachora qualeae & UB 21771 & - & - & KU682780 \\
\hline Phyllachora sp. & MM-130 & - & KX451883 & - \\
\hline Phyllachora sp. & MM-128 & - & KX451859 & KX451908 \\
\hline Phyllachora sp. & MM-129 & - & KX451860 & KX451909 \\
\hline Phyllachora sp. & MM-135 & - & KX451885 & - \\
\hline Phyllachora sp. & MM-78 & - & KX451853 & - \\
\hline Phyllachora sp. & MM-98 & $\mathrm{KX} 430502$ & KX451856 & - \\
\hline Phyllachora sp. & MM-134 & KX430479 & KX451884 & - \\
\hline Phyllachora sp. & $\mathrm{SO}-07$ & - & KX451890 & - \\
\hline Phyllachora sp. & RMB1061 & - & KX451870 & KX451921 \\
\hline Plagiostoma euphorbiae & CBS 340.78 & AF408382 & - & DQ323532 \\
\hline Pleurostoma ootheca & CMU 23858 & AY761079 & AY761074 & - \\
\hline Pleurostomophora repens & CBS H7594 & AY761078 & AY761067 & - \\
\hline Pleurothecium semifecundum & CBS 131271 & - & JQ429254 & NR111710 \\
\hline Polystigma amygdalinum & EA-1 & - & - & KC756360 \\
\hline Polystigma amygdalinum & 1276059 & KM111540 & KM111539 & - \\
\hline Polystigma pusillum & MM-113 & $\mathrm{KX} 430474$ & KX451858 & KX451907 \\
\hline Polystigma pusillum & MM-147 & - & KX451862 & - \\
\hline Polystigma pusillum & MM-19 & KX430489 & KX451850 & KX451899 \\
\hline Polystigma rubrum & MFLU15-3091 & MF981079 & - & KY594023 \\
\hline Polystigma sp. & Rub1 & - & - & KC966927 \\
\hline Polystigma sp. & MM163 & KX430487 & KX451864 & KX451916 \\
\hline Pseudomassaria chondrospora & $\mathrm{PC} 1$ & - & - & JF440982 \\
\hline Pseudomassaria chondrospora & MFLUCC 15-0545 & KR092779 & - & KR092790 \\
\hline $\begin{array}{l}\text { Pseudoneurospora } \\
\text { amorphoporcata }\end{array}$ & CBS 626.80 & FR774287 & - & 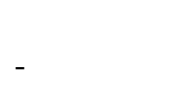 \\
\hline Pyricularia borealis & CBS 461.65 & KM009150 & KM009210 & NR145384 \\
\hline Reticulascus clavatus & CBS 125296 & GU180643 & GU180622 & NR137741 \\
\hline Robillarda sessilis & CBS 114312 & KR873284 & - & NR132928 \\
\hline Scortechiniellopsis leonensis & GKM1269 & FJ968993 & - & - \\
\hline Seimatosporium cornii & MFLUCC 14-0467 & KR559739 & KR559741 & KT162918 \\
\hline Selenodriella fertilis & CBS 772.83 & KP858992 & - & KP859055 \\
\hline Serenomyces phoenicis & PLM315 & $\mathrm{KX} 430505$ & KX451886 & - \\
\hline Seynesia erumpensnew & SMH 1291 & AF279410 & AF279409 & - \\
\hline
\end{tabular}


Table 1 Continued.

\begin{tabular}{|c|c|c|c|c|}
\hline \multirow[b]{2}{*}{ Taxon } & \multirow[b]{2}{*}{ Strain } & \multicolumn{3}{|c|}{ GenBank Accessions } \\
\hline & & LSU & SSU & ITS \\
\hline Sordaria fimicola & CBS 508.50 & - & - & AY681188 \\
\hline Stachybotrys chlorohalonata & UAMH6417 & AY489712 & AY489680 & AF206273 \\
\hline Telimena aequatoriensis & SO-05 & KX430505 & KX451886 & - \\
\hline Telimena bicincta & MM-133 & - & KX451889 & - \\
\hline Telimena bicincta & MM-108 & KX430478 & KX451861 & KX451910 \\
\hline Telimena canafistulae & MM-13 & - & KX451857 & KX451906 \\
\hline Telimena engleri & MM-153 & KX430477 & KX451849 & KX451898 \\
\hline Telimena engleri & MM-159 & - & KX451888 & KX451914 \\
\hline Telimena engleri & TH551 & - & - & KX451915 \\
\hline Telimena engleri & SO-09 & KX430511 & KX451875 & KX451895 \\
\hline Telimena leeae & ТH549 & - & - & KX451934 \\
\hline Telimena picramniae & MM-05 & KX430509 & KX451874 & - \\
\hline Telimena sp. & MM-143 & KX430470 & KX451848 & KX451896 \\
\hline Telimena sp. & MM-144 & - & KX451887 & KX451911 \\
\hline Telimena sp. & MM-92 & - & - & KX451912 \\
\hline Telimena sp. & MM- 88 & KX430501 & KX451855 & KX451905 \\
\hline Telimena sp. & MM-47 & KX430499 & KX451854 & KX451904 \\
\hline Telimena sp. & SO-14 & - & - & KX451902 \\
\hline Telimena sp. & SO-21 & - & KX451892 & KX451936 \\
\hline Telimena sp. & SO-22 & - & KX451893 & KX451937 \\
\hline Telimena ulei & SO-12 & - & KX451891 & KX451935 \\
\hline Telimena ulei & TH574 & - & KX451877 & - \\
\hline Telimena zanthoxylicola & TH550 & KX430510 & KX451879 & - \\
\hline Tilachlidium brachiatum & CBS 363.97 & KM231719 & - & KM231838 \\
\hline Togninia griseoolivacea & STE U 5966 & - & EU128058 & NR135939 \\
\hline Torpedospora radiata & AFTOL-ID 751 & DQ470951 & DQ470999 & - \\
\hline Umbrinosphaeria caesariata & CBS 102664 & AF261069 & - & - \\
\hline Vialaea mangiferae & MFLUCC 12-0808 & KF724975 & - & KF724974 \\
\hline Vialaea minutella & BRIP 56959 & KC181924 & - & KC181926 \\
\hline Xylaria hypoxylon & STMA 07069 & KM186301 & - & - \\
\hline Xylaria polymorpha & MUCL 49884 & KY610464 & - & KY610408 \\
\hline
\end{tabular}

Purification and sequencing of PCR products were carried at Sun biotech Company, Beijing, China.

Sequences generated in this study were analyzed with other sequences obtained from GenBank and recent relevant publications (Santos et al. 2016, Mardones et al. 2017) (Table 1). Dothidea sambuci (DAOM231303) was selected as the out group. Sequence data were aligned by MAFFT v. 6.864b (http://mafft.cbrc.jp/alignment/server/index.html), and edited and visually improved using Bioedit v. 7 (Hall 1999) and MEGA v.5.0 (Tamura et al. 2011). Phylogenetic analyses consisted of maximum likelihood (ML) analysis. A ML analyses was performed using raxmlGUI version 1.3 (Silvestro \& Michalak 2011). The optimal ML tree search was conducted with 1000 separate runs, using the default algorithm of the program from a random starting tree for each run. The final tree was selected among suboptimal trees from each run by comparing likelihood scores under the GTRGAMMA substitution model. The best scoring tree was selected with a final likelihood value of - 
4587.577780 Resulting trees were visualized with TreeView v. 1.6.6 (Page 1996). Sequences generated in this study were deposited in GenBank (Table 1).

\section{Results}

\section{Phylogenetic analysis}

One-hundred and ninety-eight taxa, including 37 Phyllachora-like taxa, and eight Polystigma isolates were included in the phylogenetic analysis. The best scoring RAxML tree is used as the representative tree (Fig. 1).

Three clades (A, B \& C) containing members of Phyllachoraceae were recognized within the order Phyllachorales (Fig. 1). Clade A comprised most of Phyllachora species including three-new species introduced in this study: $P$. chloridis, $P$. cynodonticola and $P$. panicicola. The $P$. graminis strains used in this analysis clustered in different places in Clade A. Phyllachora graminis strain TH544 is a sister taxon to the novel species P. chloridis. Clade B comprised 13 strains (viz. Neophyllachora cerradensis, N. myrciae, N. myrciariae, $N$. subcircinans and N. truncatisporum and Phyllachora-like sp.). Ascovaginospora sp., Coccodiella spp., Camarotella spp. and two Phyllachoralike species clustered in Clade C. Species of Polystigma grouped in three different places.

Three strains of Po. pusillum and Polystigma sp. (MM163) grouped within the order Phyllachorales, while strains of Po. amygdalinum and Po. rubrum constitute a distinct subclade within the order Xylariales .

\section{Taxonomy}

\section{Phyllachoraceae}

Phyllachoraceae is a group of host-specific, biotrophic, obligate plant parasites with a tropical distribution and is the largest family within the order Phyllachorales (Santos et al. 2016). Many of the genera of this family have less than ten species and 27 are monotypic (Mardones et al. 2017). Phyllachora is the largest genus with 994 species (Wijayawardene et al. 2017, Index Fungorum 2017).

Phyllachora chloridis Dayarathne, Shivas. \& K.D. Hyde, sp. nov.

Fig. 2

Index Fungorum number: IF552804, Facesoffungi number: FoF02907

Etymology - Epithet derived from host genus, Poaceae.

Holotype - MFLU 15-0173

Parasitic on Chloris sp. (Poaceae) and unidentified Poaceae sp. Leaf spots on host black, abundant, gregarious to scattered, raised, mostly oblong or elongated. Sexual morph: Pseudostromata 1-1.2 mm diam., subglobose, scattered, sometimes gregarious, occupying the entire section of the mesophyll, shiny black, with some carbonaceous superficial areas, multilocular. Ascomata 80-90 × 90-100 $\mu \mathrm{m}$ diam., perithecia globose, with an almost flat base, lying in leaf tissues and maturing in living leaves, ostiolate, ostiolar canal lacking periphyses. Peridium 6-12 $\mu \mathrm{m}$ wide, clypeate, opaque, black, epidermal, thickest adjacent to ostiolar canal, composed of an amorphous layer of host cuticle and epidermal cells, often merging with distorted parenchyma cells infiltrated with fungal hyphae, beneath the clypeus. Lower and lateral peridium composed of two layers; an outer region comprising several layers of dark brown, flattened, thin-walled fungal cells, which merge inwardly with several layers of hyaline, flattened, thin-walled fungal cells. The basal peridium merges outwardly with either a narrow zone of infiltrated and distorted host parenchyma and occasionally lower epidermal cells. Paraphyses $0.75-2 \mu \mathrm{m}$ wide, numerous, persistent, filiform, unbranched, aseptate, slightly longer than asci. Asci 50-72 $\times 6-8 \mu \mathrm{m}(\bar{x}=62.5 \times 7 \mu \mathrm{m}, \mathrm{n}=30), 8$-spored, persistent, cylindrical to fusiform, pedicellate, with walls uniform in thickness, not especially thickened at apex, apical ring 
inconspicuous. Ascospores $8-12 \times 3.5-4.8 \mu \mathrm{m}(\bar{x}=19.8 \times 4 \mu \mathrm{m}, \mathrm{n}=30), 1$-seriate, fusiform to oval, hyaline, aseptate, with a central, large guttule and a mucilaginous sheath. Asexual morph: Unidentified

Material examined - THAILAND, Chiang Rai, Doi Mae Salong, on living leaves of Chloris sp. (Poaceae), 17 July 2014, R.G. Shivas (MFLU 15-0173, holotype); on living leaves of Chloris sp. (Poaceae), 17 July 2014, R.G. Shivas (HKS 97415, isotype). THAILAND, Chiang Mai, Mae Taeng, $\mathrm{Pa}$ Pae, Bahn Pa Dheng, 128 Moo 3, Mushroom Research Centre, on living leaves of Poaceae sp. (Poaceae), 22 November 2015, I.D. Goonasekara (MFLU 16-2980).

Note - The main distinguishing characters of $P$. chloridis are the presence of several ascomata within a pseudostroma, occupying the entire section of the mesophyll and 0-1-guttulate, clearly fusiform to oval ascospores. Furthermore, this species is easy to demarcate from the other new species introduced here in having large, centrally guttulate ascospores. Phyllachora chloridis is related to $P$. graminis (TH544) but without support. Only two records of Phyllachora, P. cynodontis and $P$. koondrookensis have been reported from Chloris spp. in previous studies (Parbery 1967, 1971). However, $P$. chloridis is clearly distinguished from all the validly documented Phyllachora spp. including the above-mentioned species of Chloris spp. Hence, we introduce it as a new species. Morphological comparison between $P$. chloridis and related species from Chloris spp. are provided in Table 2.

Phyllachora cynodonticola Dayarathne, Goonas. \& K.D. Hyde, sp. nov.

Fig. 3

Index Fungorum number: IF552805, Facesoffungi number: FoF02908

Etymology - Epithet derived from host genus Cynodon.

Holotype - MFLU 16-2977

Parasitic on Poaceae sp. Sexual morph: Leaf spots, 0.6-1 mm wide on host black, abundant, scattered, elongated, parallel with leaf venation, surrounded by yellow necrotic region. Pseudostromata 0.7-1 mm wide, subglobose, scattered, sometimes gregarious, occupying the entire leaf section, shiny black, with some carbonaceous superficial areas. Ascomata 248-320 $\mu \mathrm{m}$ wide, flattened, globose, with thin walls, lying in leaf tissues and maturing in living leaves, ostiolate, with a clypeus formed by the lateral proliferation of ostiolar hyphae. Peridium 28-39 $\mu \mathrm{m}$, clypeate, composed of black, amorphous layer of host cuticle and epidermal cells, often merging with a lighter pigmented region of yellowish, distorted parenchyma cells infiltrated with fungal hyphae, beneath the clypeus. Lower and lateral peridium composed of two layers; an outer region comprising several layers of black, flattened, thin-walled fungal cells, which merge inwardly with several layers of hyaline, flattened, thin-walled fungal cells. Lateral peridium fuses outwardly with an irregular, narrow region of distorted host parenchyma infiltrated by fungal cells. The basal peridium merges outwardly with either a narrow zone of infiltrated and distorted host parenchyma and or integrates directly with a lower clypeus. Paraphyses 1.6-2.4 $\mu \mathrm{m}$ wide, numerous, persistent, filiform, aseptate, branched. Asci 48-80 × 16-18 $\mu \mathrm{m}(\bar{x}=50.5 \times 15.6 \mu \mathrm{m}, \mathrm{n}=30), 8$-spored, persistent, cylindrical to fusiform, short pedicellate, with walls uniform in thickness, not specially thickened at apex, apical apparatus often present rarely absent, J-. Ascospores 10-12 × 5-7 $\mu \mathrm{m}(\bar{x}=11.5 \times 7 \mu \mathrm{m}, \mathrm{n}=30)$, overlapping $1-2$ seriate, fusoid, acute at the ends, with a central concave depression, hyaline, with a mucilaginous sheath. Asexual morph: Unidentified.

Material examined - THAILAND, Chiang Rai, Doi Hang, Amphoe Muang, Mae Korn, roadside near Khun Korn Waterfall, on living leaves of Cynodon sp. (Poaceae), 21 January 2015, I.D. Goonasekara (MFLU 16-2977, holotype); on living leaves of Cynodon sp. (Poaceae), 21 January 2015, I.D. Goonasekara (HKS 97414, isotype). THAILAND, Chiang Mai, Mae Taeng, Pa Pae, Bahn Pa Dheng, 128 Moo 3, Mushroom Research Centre, on living leaves of Imperata sp. (Poaceae), 22 December 2015, I.D. Goonasekara (MFLU 16-2978). 


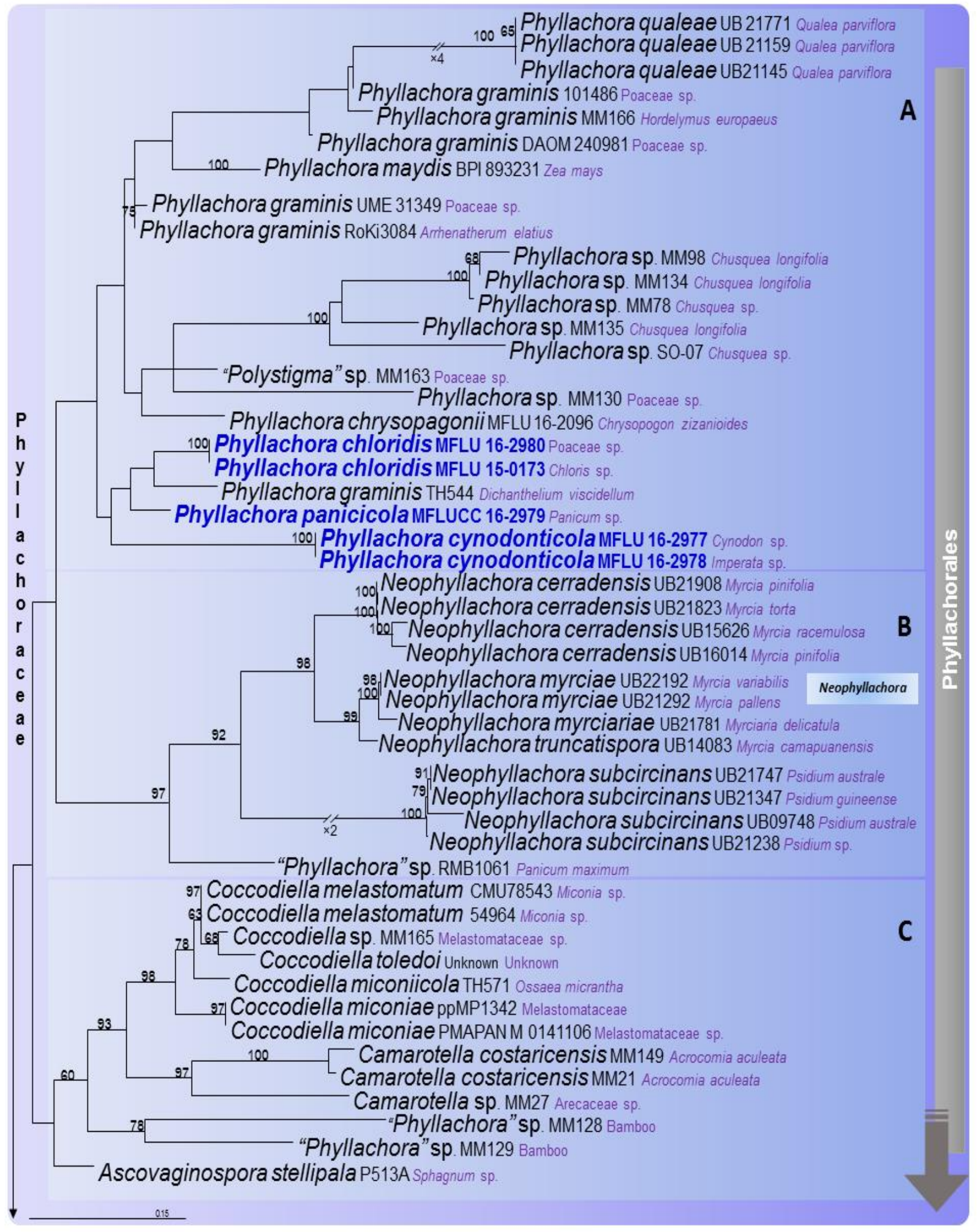




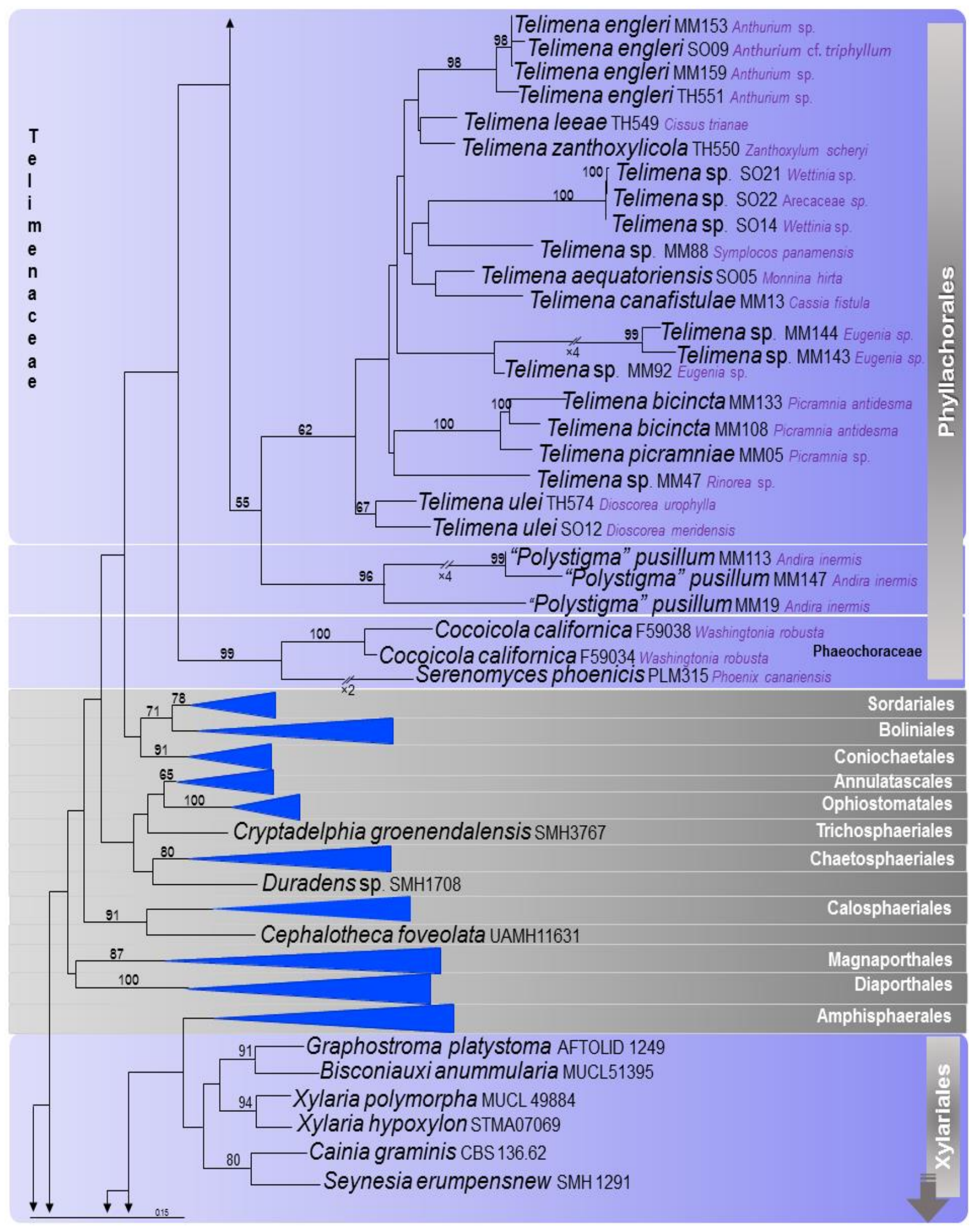




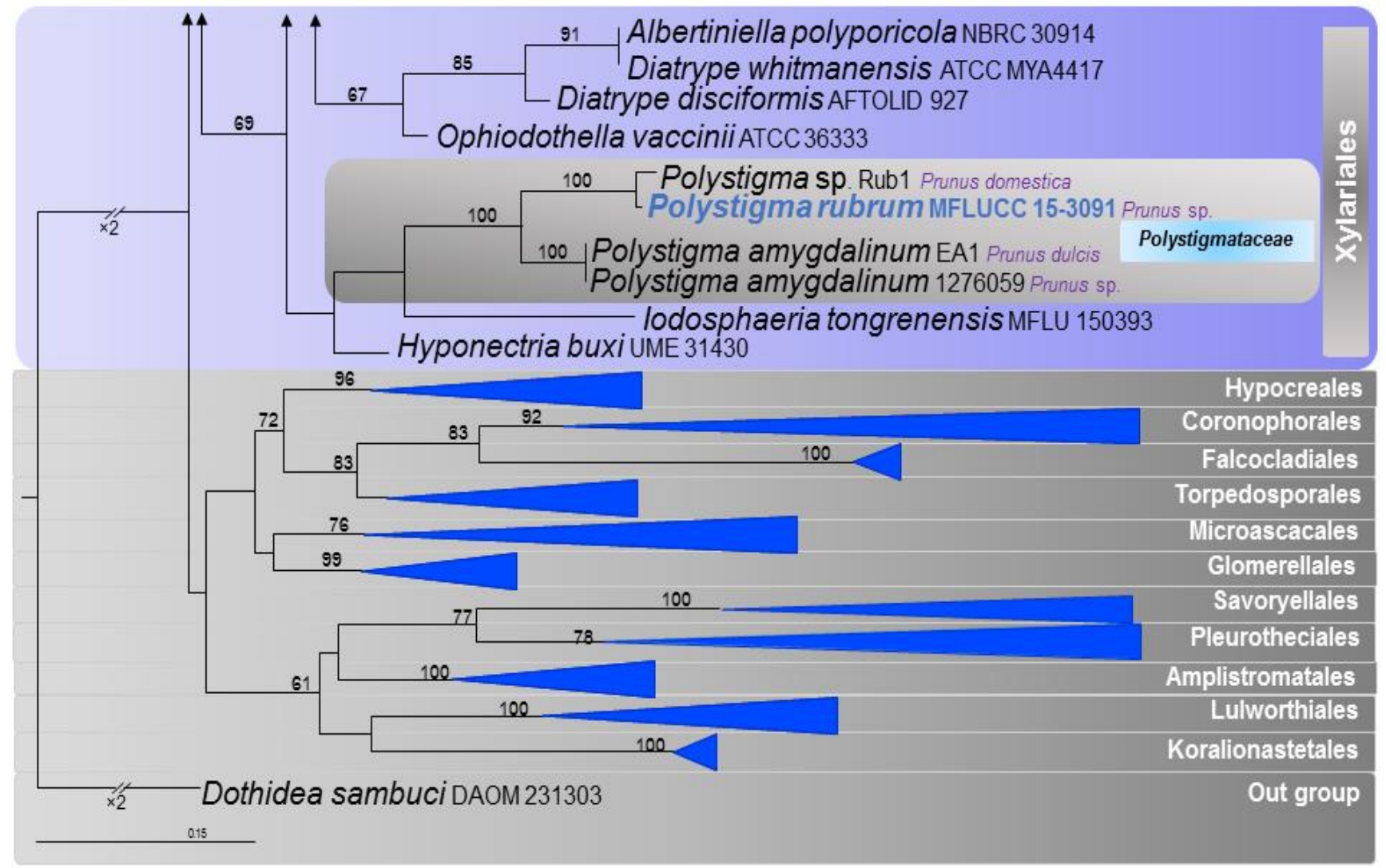

Figure 1 - Best scoring RAxML tree based on analysis of combined LSU, SSU and ITS sequence data. Maximum likelihood bootstrap values (ML, black) $\geq 60 \%$ are given above the branches. The tree is rooted to Dothidea sambuci (DAOM 231303). Newly generated strains are in blue.

Notes - Phyllachora cynodonticola differs from other Phyllachora species in forming leaf spots surrounded by yellow necrotic regions and 1-2 seriate fusoid, ascospores which are acute at the ends, with a central concave depression and a mucilaginous sheath. Phyllachora cynodonticola differs from $P$. panicicola in the arrangement of ascospores inside the asci and by having relatively smaller ascospores $(10-12 \times 5-7 \mu \mathrm{m}$ vs 14-16 $\times 6-8 \mu \mathrm{m})$, whereas, it can be distinguished from $P$. chloridis by having ascospores with a central concave depression. Phylogenetic analysis showed that $P$. cynodonticola has a close affinity to $P$. panicicola, but they showed $8 \%$ nucleotide differences in the ITS region out of 497 base pairs. Phyllachora cynodontis is the only species previously described from Cynodon spp. and is clearly different from $P$. cynodonticola mainly from the presence of ovoid ascospores lacking central concave depression and relatively smaller asci $(20-25 \times 12-15$ vs 48-80 $\times$ 16-18) (Table 2). Phyllachora cynodonticola and P. graminis (type) are also well distinguished morphologically, due to the presence of a centrally located concave depression and a mucilaginous sheath surrounding the ascospores of $P$. cynodonticola, which cannot be observed in $P$. graminis.

Phyllachora panicicola Dayarathne \& K.D. Hyde, sp. nov.

Fig. 4

Index Fungorum number: IF552806, Facesoffungi number: FoF02909

Etymology - Epithet derived from host genus Panicum.

Holotype - MFLU 16-2979

Parasitic on Panicum sp. (Poaceae) Sexual morph: Leaf spots on host black, abundant, scattered, raised, oblong or elongated. Pseudostromata $0.7-1 \mathrm{~mm}$ wide, subglobose, scattered, sometimes gregarious, occupying the entire leaf section, shiny black, with some carbonaceous 

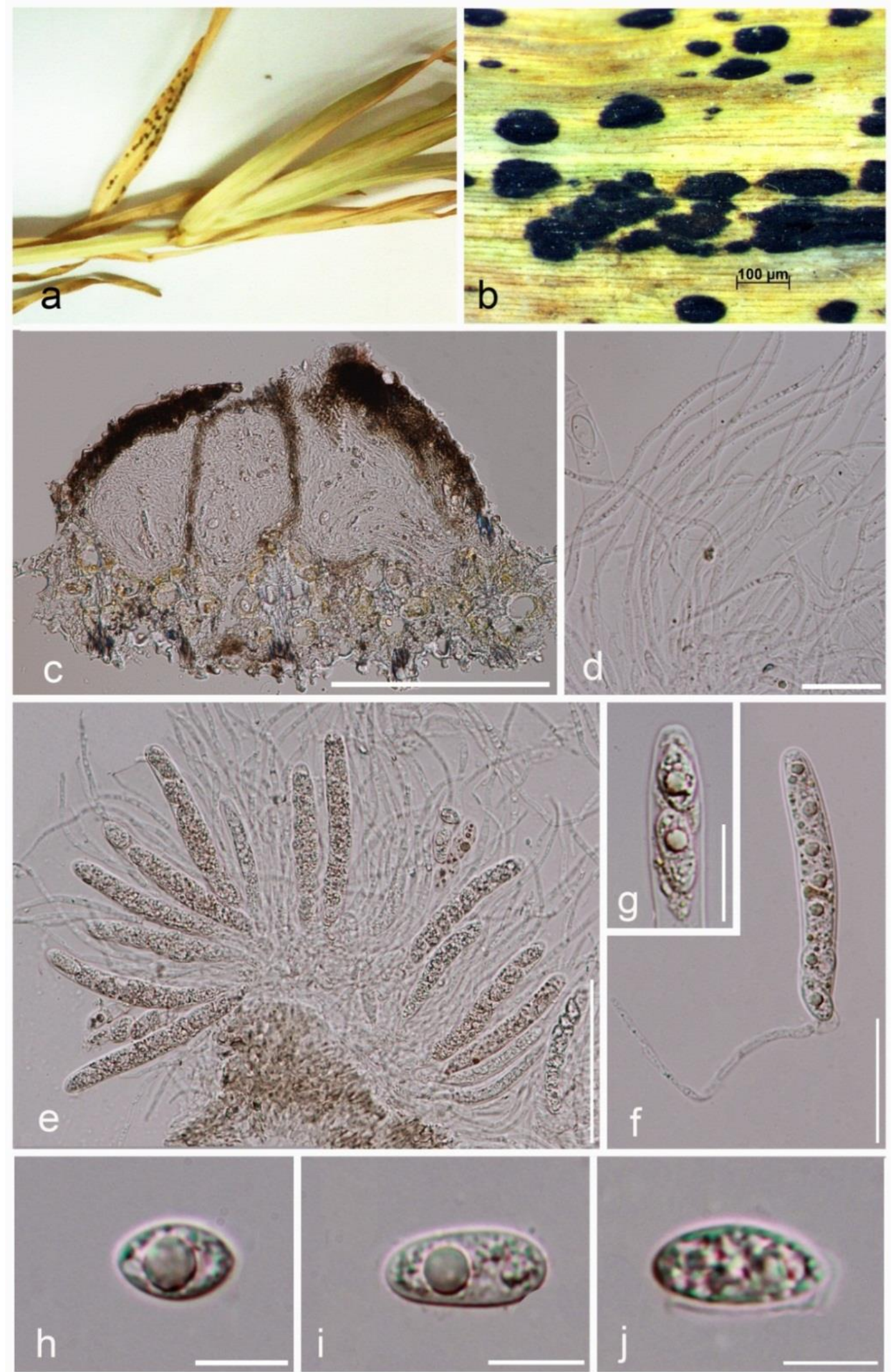

Figure 2 - Phyllachora chloridis (MFLU 15-0173 holotype) a,b. Tar spots on living leaves of Chloris sp. (Poaceae). c. Section through pseudostroma. d. Paraphyses. e,f. Asci. g. Apex of asci $h-j$. Ascospores. Scale bars: $\mathrm{b}=100 \mu \mathrm{m}, \mathrm{c}=50 \mu \mathrm{m}, \mathrm{e}, \mathrm{f}=20 \mu \mathrm{m}, \mathrm{d}=10 \mu \mathrm{m}$. 

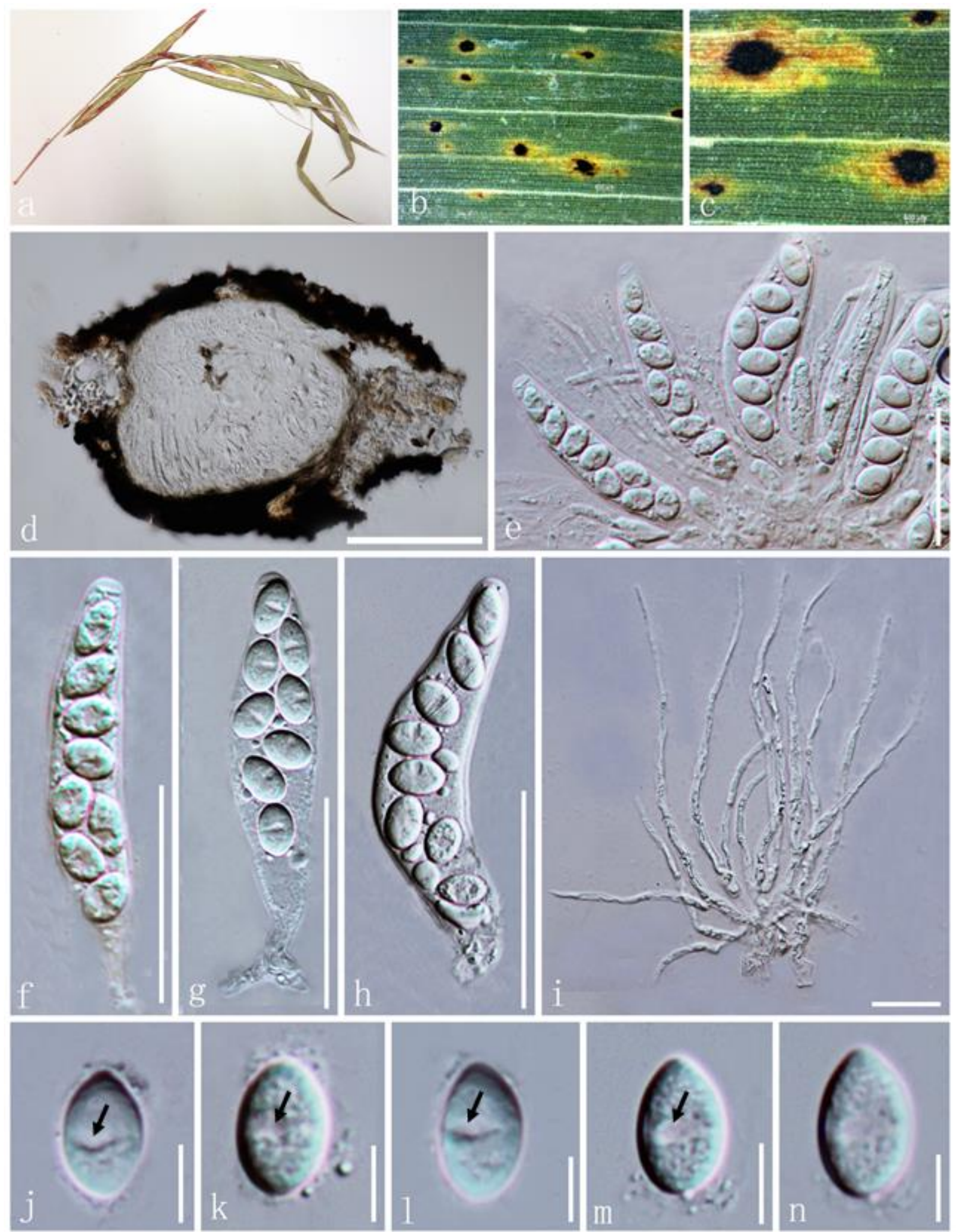

Figure 3 - Phyllachora cynodonticola (MFLU 16-2977 holotype).a. Tar spots on leaves of Cynodon sp. b,c. Close up of tar spots on host. d. Section through pseudostroma. e. Asci and paraphyses. f-h. Asci. i. Paraphyses. $\mathrm{j}-\mathrm{n}$. Ascospores (arrow indicates the central concave depression). Scale bars: $\mathrm{b}=$ $500 \mu \mathrm{m}, \mathrm{d}=100 \mu \mathrm{m}, \mathrm{e}-\mathrm{h}=50 \mu \mathrm{m}, \mathrm{i}=10 \mu \mathrm{m}, \mathrm{j}-\mathrm{n}=5 \mu \mathrm{m}$. 
superficial areas. Ascomata 300-500 $\times 250-300 \mu \mathrm{m}$. globose to subglobose, lying in leaf tissues and maturing in living leaves, ostiole inconspicuous. Peridium 30-45 $\mu \mathrm{m}$ wide, clypeate, equally thickened, composed of a deeply melanized, black, amorphous layer of host cuticle and epidermal cells, distorted parenchyma cells infiltrated with fungal hyphae, beneath the clypeus, covering the entire pseudostroma. Lower and lateral peridium composed of two layers; an outer region comprising several layers of black, thick-walled fungal cells, which merge inwardly with several layers of hyaline, flattened, thin-walled fungal cells. The basal peridium fuses outwardly with lower clypeus. Paraphyses 1-3 $\mu \mathrm{m}$ wide, numerous, persistent, filiform, branched, slightly longer than asci. Asci 110-130 $\times 10$ $14 \mu \mathrm{m}(\bar{x}=118.7 \times 12.4 \mu \mathrm{m}, \mathrm{n}=30), 8$-spored, persistent, cylindrical to fusiform, pedicellate, with walls uniform in thickness. Ascospores 14-16 $\times 6-8 \mu \mathrm{m}(\bar{x}=15.6 \times 7 \mu \mathrm{m}, \mathrm{n}=30)$, overlapping 1seriate, ellipsoidal, rounded at the ends, with a central concave depression, hyaline, with a thick mucilaginous sheath, 2-3 $\mu \mathrm{m}$ wide. Asexual morph: Unidentified.

Material examined - CHINA, Yunnan Province, Kunming, Botanical garden of Kunming Institute of Botany, on living leaves of Panicum sp. (Poaceae), 15 August 2016, M. Dayarathne TAR01 (MFLU 16-2979, holotype); on living leaves of Panicum sp. (Poaceae), 15 August 2016, M. Dayarathne TAR01 (HKS 97416, isotype).

Notes - Phyllachora panicicola is characterized by the presence of pseudostromata occupying the entire leaf section and oval ascospores with a thick mucilaginous sheath. Phylogenetically this species clearly differs from all the other species used in this analysis. Phyllachora bonariensis, $P$. mayorii, P. microsperma, P. minutissima, P. panici-proliferi, P. paspalicola, $P$. punctum, $P$. stenospora, $P$. tetrasporicola and $P$. urvilleana are the other species which have been reported from Panicum spp. (Parbery 1967, 1971). Phyllachora panicicola is most similar to P. punctum but can be distinguished by the presence of central concave depression and thick mucilaginous sheath surrounding the ascospores, of the former. A synopsis of P. panicicola and other Phyllachora species recorded from Panicum is provided in Table 2.

Neophyllachora Dayarathne \& K.D. Hyde, gen. nov.

Index Fungorum number: IF553633, Facesoffungi number: FoF02909

Parasitic on Myrtaceae species. Sexual morph: Leaf spots on host black, abundant, scattered, oblong or elongated. Pseudostromata subcuticular to intra-epidermal, sometimes occupying the palisade mesophyll layer, circular to irregular or scutiform to hemispherical, gregarious, sparse or coalescent, glabrous, shiny, black, uni to multi-locular (1-12 locules), epiphyllous or amphigenous, often covering most of the leaf surface. Ascomata perithecial, ampulliform, immersed in pseudostromatic tissue, ostiolate, clypeate; ostiole conspicuous, periphysate; peridium showing layers of compressed melanized cells; clypei well developed, black, hymenium coating the base and the sidewall of the ascomata. Paraphyses numerous, filiform or clavate, hyaline, septate, unbranched, thin-walled. Asci 8spored, unitunicate, cylindrical or clavate-fusoid, short-pedicellate, apex obtuse or tapered with a slight thickening, without a conspicuous apical ring. Ascospores unicellular, hyaline when immature to light olivaceous at maturity, 1-2-seriate, oblong to ellipsoid or sublunate to lunate, with guttules, surrounded by a gelatinous sheath or with thickened walls at its acute apices. Asexual morph: Conidiomata spermatial or conidial, black, immersed in same pseudostromata containing the ascomata. Spermatial locules ampulliform, ostiolate; spermatogenous cells hyaline, phialidic, covering internal wall of the conidiomata. Spermatia falcate, curved, aseptate, hyaline, with rounded subtruncate ends. Conidiogenous cells holoblastic, lageniform, covering the base of the conidiomata. Conidia mostly clavate, ellipsoidal to fusiform or oblong, straight or curved.

Type species - Neophyllachora myrciae (Lév.), Dayarathne \& K.D. Hyde 


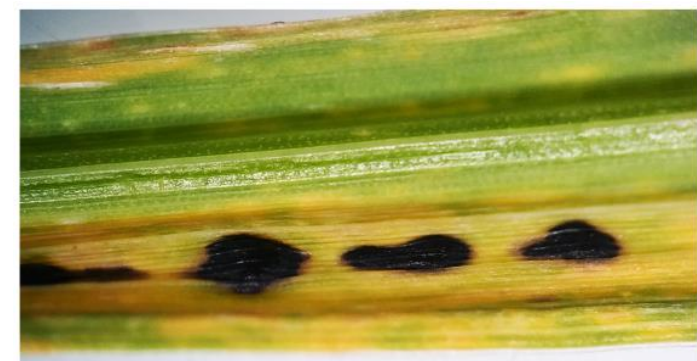

a
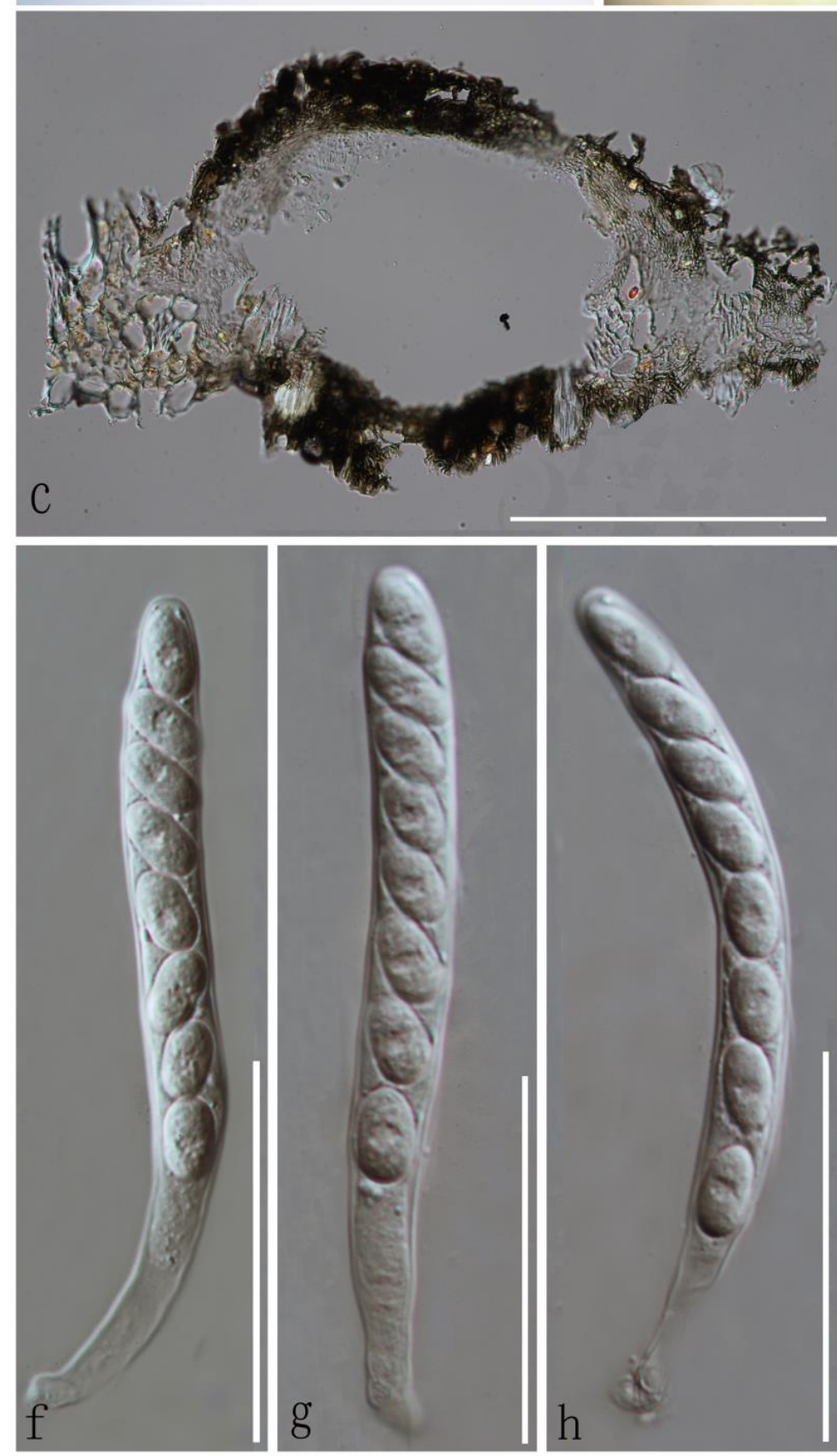
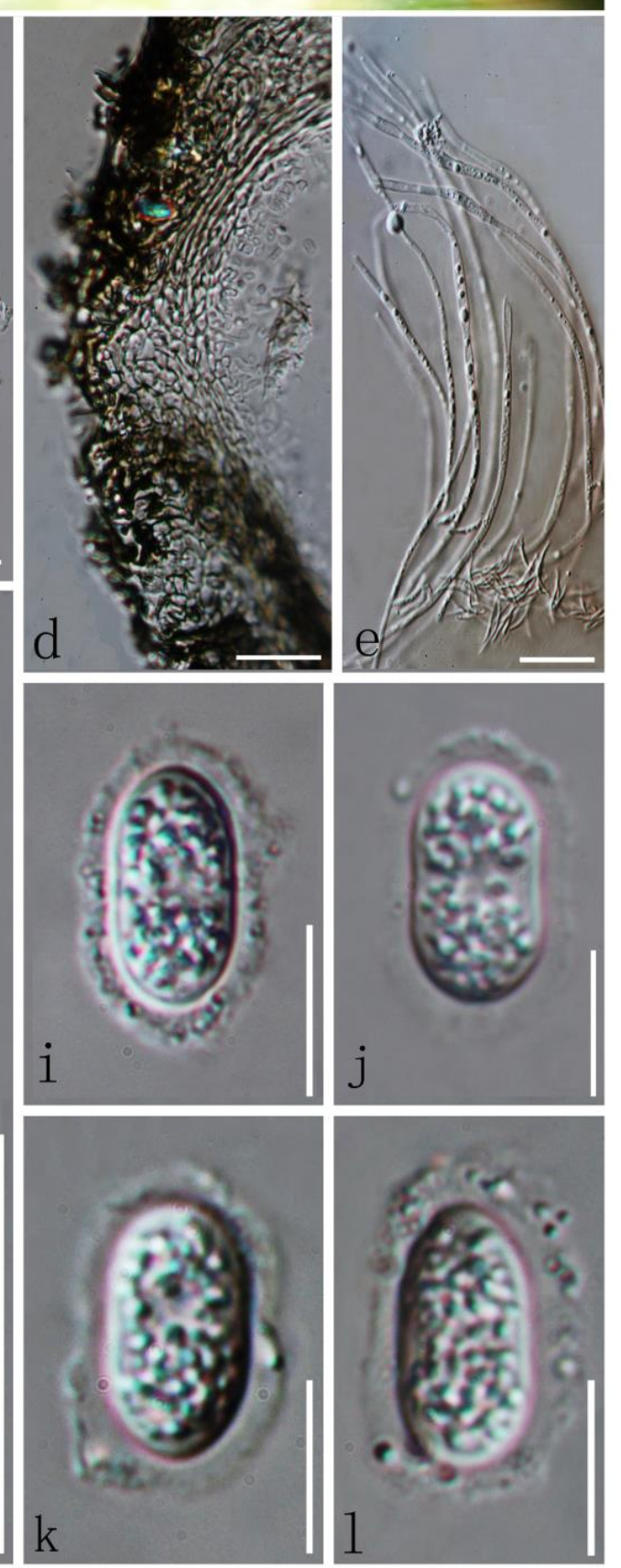

Figure 4 - Phyllachora panicicola (MFLU 16-2979 holotype) a. Tar spots on Panicum sp. b. Close up of tar spots on host. c. Section through pseudostroma. d. Peridium. e. Paraphyses. f,h. Asci. i-l. Ascospores. Scale bars: $\mathrm{c}=100 \mu \mathrm{m}, \mathrm{f}-\mathrm{k}=50 \mu \mathrm{m}, \mathrm{d}, \mathrm{e}=20 \mu \mathrm{m}, \mathrm{i}-1=10 \mu \mathrm{m}$. 
Table 2 Morphological comparison between $P$. chloridis, P. panicicola and $P$. cynodonticola with related species reported from Poaceae

\begin{tabular}{|c|c|c|c|c|c|c|c|}
\hline \multirow[b]{2}{*}{ Species } & \multirow{2}{*}{$\begin{array}{l}\text { Asci } \\
(\mu \mathrm{m})\end{array}$} & \multicolumn{3}{|c|}{ Ascospores } & \multirow[b]{2}{*}{ Locality } & \multirow[b]{2}{*}{ Host } & \multirow[b]{2}{*}{ Reference } \\
\hline & & $\begin{array}{l}\begin{array}{l}\text { Size } \\
(\mu \mathrm{m})\end{array} \\
\end{array}$ & $\begin{array}{l}\text { No. of } \\
\text { septa }\end{array}$ & Shape & & & \\
\hline P. bonariensis & $\begin{array}{l}45-84 \times \\
9-16\end{array}$ & $\begin{array}{l}13-17 \\
\times 5-7\end{array}$ & $0-1$ & Fusoid & $\begin{array}{l}\text { Australia, central/ southern } \\
\text { Africa, central/ south America, } \\
\text { Japan, Java, Nepal, Taiwan, } \\
\text { West Indies }\end{array}$ & Panicum sp. & Parbery 1967, 1971 \\
\hline P. chloridis & $\begin{array}{l}50-72 \times \\
6-8\end{array}$ & $\begin{array}{l}8-12 \times \\
3.5- \\
4.8\end{array}$ & Aseptate & Fusiform to oval & Thailand & $\begin{array}{l}\text { Chloris sp., } \\
\text { Poaceae sp. }\end{array}$ & This study \\
\hline P. cynodonticola & $\begin{array}{l}48-80 \times \\
16-18\end{array}$ & $\begin{array}{l}10-12 \\
\times 5-7\end{array}$ & Aseptate & $\begin{array}{l}\text { Fusoid, acute at } \\
\text { the ends }\end{array}$ & Thailand & $\begin{array}{l}\text { Cynodon sp., } \\
\text { Imperata sp. }\end{array}$ & This study \\
\hline P. cynodontis & $\begin{array}{l}20-25 \\
\mathrm{p} 12-15 \\
\mathrm{p}\end{array}$ & $\begin{array}{l}8-15 \\
\text { by } 5-6 \\
\text { p. }\end{array}$ & $0-1$ & Ovoid & World wide & Chloris sp. & Parbery 1967, 1971 \\
\hline P. graminis & $\begin{array}{l}80-90 \times \\
8-9.5\end{array}$ & $\begin{array}{l}9-11 \times \\
6-7\end{array}$ & Aseptate & Fusiform to oval & World wide & Poa sp. & Parbery 1967, 1971 \\
\hline P. mayorii & $\begin{array}{l}51-72 \times \\
10-11\end{array}$ & $\begin{array}{l}10-12 \\
\times 4.5\end{array}$ & Aseptate & $\begin{array}{l}\text { Naviculoid or } \\
\text { elongate ovoid }\end{array}$ & Colombia & Panicum sp. & Parbery 1967,1971 \\
\hline P. microsperma & $45 \times 7$ & $\begin{array}{l}7-7.5 \\
\times \quad 4.5- \\
5\end{array}$ & Aseptate & $\begin{array}{l}\text { Oval to } \\
\text { broadly ellipsoid }\end{array}$ & Brazil & Panicum sp. & Parbery 1967,1971 \\
\hline P. minutissima & $\begin{array}{l}65-125 \\
\times 10-18\end{array}$ & $\begin{array}{l}17-24 \\
\times 7-11\end{array}$ & Aseptate & $\begin{array}{l}\text { Ovate-acuminate } \\
\text { (not extreme) to } \\
\text { ovoid or oval }\end{array}$ & Angola & Panicum sp. & Parbery 1967,1971 \\
\hline P. panicicola & $\begin{array}{l}110-130 \\
\times 10-14\end{array}$ & $\begin{array}{l}14-16 \\
\times 6-8\end{array}$ & Aseptate & $\begin{array}{l}\text { Ellipsoidal, } \\
\text { rounded at the } \\
\text { ends }\end{array}$ & China & Panicum sp. & This study \\
\hline
\end{tabular}


Table 2 Continued.

\begin{tabular}{|c|c|c|c|c|c|c|c|}
\hline \multirow[b]{2}{*}{ Species } & \multirow[b]{2}{*}{$\begin{array}{l}\text { Asci } \\
(\mu \mathrm{m})\end{array}$} & \multicolumn{3}{|c|}{ Ascospores } & \multirow[b]{2}{*}{ Locality } & \multirow[b]{2}{*}{ Host } & \multirow[b]{2}{*}{ Reference } \\
\hline & & $\begin{array}{l}\text { Size } \\
(\mu \mathrm{m})\end{array}$ & $\begin{array}{l}\text { No. of } \\
\text { septa }\end{array}$ & Shape & & & \\
\hline P. paspalicola & $\begin{array}{l}60-90 \times \\
8-12\end{array}$ & $\begin{array}{l}10-12 \\
\times 6-8\end{array}$ & Aseptate & $\begin{array}{l}\text { Subglobose to } \\
\text { broadly ellipsoid, } \\
\text { rarely ovoid }\end{array}$ & $\begin{array}{l}\text { Australia, central and South } \\
\text { America, Japan, Papua New } \\
\text { Guinea, Philippines, South } \\
\text { Africa, West Africa, West } \\
\text { Indies }\end{array}$ & Panicum sp. & Parbery 1967,1971 \\
\hline P. punctum & $\begin{array}{l}75-90 \times \\
8-10\end{array}$ & $\begin{array}{ll}9-1 & 3 \\
\times & 4- \\
5.5 & \end{array}$ & Aseptate & $\begin{array}{l}\text { Ellipsoid } \\
\text { occasionally, } \\
\text { oval-ovate }\end{array}$ & $\begin{array}{l}\text { Australia, Brazil, Canada, } \\
\text { India, South Africa, United } \\
\text { States }\end{array}$ & Panicum sp. & Parbery 1967,1971 \\
\hline P. stenospora & $\begin{array}{l}52-68 \times \\
8-10\end{array}$ & $\begin{array}{l}7.5-10 \\
\times 3.5- \\
4\end{array}$ & Aseptate & Lacriform & Philippines, Sri-Lanka & Panicum sp. & Parbery 1967 \\
\hline P. tetrasporicola & $\begin{array}{l}65-85 \\
\text { by } 8-10 \\
\text { p }\end{array}$ & $\begin{array}{l}15-19 \\
\text { by } 6-7 \\
\text { p. }\end{array}$ & Aseptate & $\begin{array}{l}\text { Fusiform } \\
\text { to ovate- } \\
\text { acuminate }\end{array}$ & Dominican Republic & Panicum sp. & Parbery 1967,1971 \\
\hline P. urvilleana & $\begin{array}{l}60-70 \times \\
7-8\end{array}$ & $\begin{array}{l}18-20 \\
\times 4\end{array}$ & Aseptate & Fusiform & $\begin{array}{l}\text { Argentina, Buenos Aires, Bahía } \\
\text { Blanca; Puerto Argentino }\end{array}$ & Panicum sp. & $\begin{array}{l}\text { http://www.cybertruffle. } \\
\text { org.uk/spegazzini/eng/0 } \\
\text { 00192a }\end{array}$ \\
\hline
\end{tabular}

Notes - Members of Neophyllachora are subepidermal, intra-epidermal stromata without a deeper invasion of the mesophyl, and clavate asci; three species appear specifically infecting Myrcia species, one on Myrciaria species, and one on different Psidium species. Phyllachora myrciae has characteristically lunate ascospores, and two types of conidia (ellipsoidal and falcate) formed in separate conidiomata, but both showing phialidic conidiogenesis; P. trucatisporum on Myrcia camapuanensis has sublunate ascospores with both ends showing characteristic wall thickenings; $P$. cerradensis on $M$. torta shows elliptical ascospores with predominantly longer dimensions when compared to $P$. subcircinans, which is found only on Psidium species; finally $P$. myrciariae shows ascospores similar in form to those of $P$. cerradensis, but also forms fusoid-clavate phialidic conidia. According to our phylogenetic analysis the species belongs to Neophyllachora. 
Neophyllachora myrciae (Lév.), Dayarathne \& K.D. Hyde, comb. nov.

Index Fungorum number: IF553591

三 Catacauma myrciae (Lév.) Theiss. \& Syd., Ann. Mycol. 13(3/4):393. 1915

三Dothideamyrciae Lév., Ann. Sci. Nat. Bot. 5:264. 1846.

Description - see Santos et al. (2016)

Notes - Phyllachora myrciae was described as Dothidea myrciae Lév. on Myrcia sp. from an undefined location in Brazil (Saccardo 1883). Well-illustrated species were described by Viégas (1948) on the basis of material collected in 1936 from Cerrado on Eugenia bimarginata, which is now confirmed as a Myrcia species. It has also been reported in 1943 from M. vestita (Santos et al. 2016). It is shown to have a broad host spectrum of species, but within the genus Myrcia causing tar spots in six different species ( $M$. decrescens, $M$. dictyophylla, $M$. guianensis, $M$. nivea, $M$. variabilis, $M$. vestita). All of them produce the same type of pseudostroma, precisely drawn by Viégas (1944), with fusoid asci containing the typically lunate ascospores, and falcate spermatial conidia on a pseudostromatic conidiomata.

Neophyllachora cerradensis (Santos, R.B. Medeiros \& Dianese), Dayarathne \& K.D. Hyde, comb. nov.

Index Fungorum number: IF553592

$\equiv$ Phyllachora cerradensis Santos, R.B. Medeiros \& Dianese, in Santos, Fonseca-Boiteux,

Boiteux, Câmara \& Dianese, Mycologia 108(6): 1151 (2016)

Description - see Santos et al. (2016)

Notes - The main characteristics of $N$. cerradensis are the shape of the conidia (mostly clavate), and clearly elliptical ascospores formed within fusoid asci. This species was studied, but not properly described by Medeiros (1994). Later on Santos et al. (2016) properly described this species together with an asexual morph and introduced it as a new species to the genus Phyllachora based on morpho-molecular data. According to phylogenetic analysis of combined LSU, SSU and ITS data, all isolates of $N$. cerradensis cluster in a strongly supported subclade (Fig. 1) and share a close relationship to $N$. myrciae, $N$. myrciariae, $N$. subcircinans and $N$. truncatispora.

Neophyllachora myrciariae (Santos \& Dianese), Dayarathne, Maharachch. \& K.D. Hyde, comb. nov.

Index Fungorum number: IF553593

$\equiv$ Phyllachora myrciariae Santos \& Dianese, Mycologia 108(6): 1151 (2016)

Description - see Santos et al. (2016)

Notes - Neophyllachora myrciariae is the first report of a Phyllachora species associated with plants belonging to genus Myrciaria (Santos et al. 2016). Neophyllachora myrciariae can be recognized by intra-epidermal pseudostromata and hyaline, elliptical, irregularly guttulate ascospores covered by a mucoid sheath (Santos et al. 2016). According to our phylogenetic analysis this species formed a well-separated lineage (100\% ML) basal to N. myrciae.

Neophyllachora subcircinans (Speg.), Dayarathne, Maharachch. \& K.D. Hyde, comb. nov.

Index Fungorum number: IF553594

$\equiv$ Phyllachora subcircinans Speg., Revista Argent. Hist. Nat. 1(6): 413 (1891)

三Catacauma subcircinans (Speg.) Theiss. \& Syd., Annls mycol. 13(3/4): 394 (1915)

Description - see Santos et al. (2016)

Notes - Neophyllachora subcircinans comprises subcuticular, partially intraepidermal, epiphyllous, occasionally amphigenous, pseudostromata. Ascospores are hyaline when immature becoming light olivaceous at maturity, guttulate in the middle portion, with irregularly shaped guttules and a thin wall surrounded by a gelatinous sheath. This species was introduced by Spegazzini in 1891 based only on morphological data. Santos et al. (2016) treated this species based on molecular data and grouped in a subclade with Phyllachora species parasitic on Psidium species and it is closely related to other species within this clade by having subcuticular, 
intradermal or subepidermal pseudostromata. This is supported by our phylogenetic analysis with combined LSU, SSU and ITS data.

Neophyllachora truncatispora (Viégas), Dayarathne, Maharachch. \& K.D. Hyde, comb. nov.

Index Fungorum number: IF55359

三 Catacauma truncatisporum Viégas, Bragantia 4(1-6): 145 (1944)

EPhyllachora truncatispora (Viégas) Bat. \& H. Maia, in Batista, Peres \& Maia, Atas Inst.

Micol. Univ. Recife 4: 70 (1967)

Description - see Santos et al. (2016)

Notes - Neophyllachora truncatispora is characterized by having sublunate to fusoid, hyaline, smooth-walled, ascospores with characteristic wall thickenings at both acute ends (Viégas 1944). The asexual morph, a stromatic coelomycete comprising filiform, curved, hyaline conidia, tapered on both ends (Santos et al. 2016). In our phylogenetic analysis, it formed a well separated (99\% ML) clade basal to a group comprising $N$. myrciae, $N$. myrciariae and $N$. subcircinans.

\section{Key to species of Neophyllachora}

1. Parasitic on Myrcia or Myrciaria species; ascospores ellipsoidal or lunate....................2

1. Parasitic on Psidium species; ascospores short-ellipsoidal, oblong to subglobose..N. subcircinans

2. Parasitic on Myrciaria delicatula; asexual morph with fusoid-clavate conidia.......... myrciariae

2. Parasitic on Myrcia species; asexual morph unknown or with filiform conidia.................... 3

3. Ascospores ellipsoidal, on Myrcia torta .................................... cerradensis

3. Ascospores typically lunate or lunate-reniform to half-moon shape, on several Myrcia species...4

4. Ascospores lunate-reniform to half-moon shape, with accute wall thickenings at both ends; on Myrcia camapuanensis

N. truncatispora

4. Ascospores lunate, without acute wall thickenings at both ends, on $M$. decrescens, $M$. dictyophylla, M. guianensis, M. nivea, M. variabilis, and $M$. vestita. N. myrciae

Polystigmataceae Höhn. ex Nannf., 1932

Facesoffungi number: FoF03518

Parasitic on living leaves and shoots of Rosaceae. Stromata mostly developing through late spring and summer on living leaves or young shoots, producing conidia in summer and autumn, and ascospores from fallen overwintered leaves the following spring, scattered, slightly raised, irregular, orange or reddish-brown to black, sometimes purplish-black, bordered by apparently healthy leaf tissue. Asexual morph: Conidial stromata irregularly-shaped, yellowish-brown in very young lesions, but quickly becoming orange to reddish-brown to black, becoming darker in the central region, hologenous, sometimes distorting the leaves and shoots, the surrounding leaf tissue hardly affected, containing a large number of conidiomata, composed of an upper layer of plant whose cells are filled with bright orange-brown material, an intermediate layer of almost completely occluded angular to vertically elongated fungal cells, and the lower layer similar to the upper one. Conidiomata sphaerical, epigenous or hologenous, the ostiole inconspicuous, papillate or apapillate. Conidiomatal wall poorly-developed, not clearly distinguishable or composed of hyaline thick-walled cells of textura angularis. Conidiogenous cells cylindrical, tapering towards the upper region, which are slightly irregular in appearance due to successive conidial scars, usually proliferating sympodially, developing over the entire inner surface of the wall, arising as lateral or terminal branches from short relatively undifferentiated conidiophores. Conidia the lower part narrowly lanceolate to fusiform, the upper part filiform, sigmoidally curved, the base truncate, hyaline, aseptate, apparently smooth-walled. Sexual morph: Ascostromata irregularly-shaped, usually roughly circular, strongly raising the adaxial surface of the leaf, flat or slightly concave on the abaxial surface, hologenous, reddish-brown to black, sometimes faintly verrucose, the ostioles sometimes inconspicuous, but appearing as small black dots on paler stromata, often somewhat sunken, composed of pigmented outer layers and a hyaline inner layer containing the ascomata. 
Ascomata sphaerical. Paraphyses sparse, gradually tapering towards the apex, very thin-walled, strongly inflated between the septa. Asci 8-spored, unitunicate, clavate, long-pedicellate, thinwalled at all stages, the apex obtuse, with an apical ring. Ascospores biseriate, cylindrical to ellipsoidal or obovoid, occasionally slightly curved (fabiform), hyaline, aseptate, without a gelatinous sheath (Modified description based on Cannon 1996).

Type genus - Polystigma DC., in de Candolle \& Lamarck, 1815

Type species - Polystigma rubrum (Pers.) DC., in de Candolle \& Lamarck, 1815

Notes - The family Polystigmataceae is characterized by astromatic or poorly-developed stroma, whose ascal apices do not stain blue with iodine and ascospores without germ pores or slits. Another characteristic feature of the family is the production of appressoria by the germinating ascospores. Most of the species are parasites and cause diseases of economically important plants (Mehrotra \& Aneja 1990). Dennis (1968, 1977), Muller \& von Arx (1973) and Hawksworth et al. (1983) have included the members of Phyllachoraceae within this family and did not recognize Phyllachoraceae as a separate family. Hawksworth et al. (1983) have raised it to the ordinal rank, Polystigmatales (Phyllachorales) and included a single family Phyllachoraceae with about 23 genera in this order (Mehrotra \& Aneja 1990). Since then, species of Polystigma were placed within Phyllachoraceae. Habibi et al. (2015) reported that Polystigma amygdalinumis, which was previously placed in Phyllachorales (subclass Sordariomycetidae) was not related to Phyllachora species but clustered in the subclass Xylariomycetidae. Our phylogenetic analysis of combined LSU, SSU and ITS data confirms that taxa of Polystigma are phylogenetically distant from the Phyllachorales, and belongs to the order Xylariales. Hence, the family Polystigmataceae is reestablished within the subclass Xylariomycetidae.

Polystigma DC., in de Candolle \& Lamarck, Fl. franç., Edn 3 (Paris) 6: 164 (1815)

Facesoffungi number: FoF03519

Parasitic on living leaves of Rosaceae. Stromata mostly developing through late spring and summer on living leaves or young shoots, producing conidia in summer and autumn, and ascospores from fallen overwintered leaves the following spring, scattered, slightly raised, irregular, orange or reddish-brown to black, sometimes purplish-black, bordered by apparently healthy leaf tissue. Asexual morph: Conidial stromata irregularly-shaped but usually roughly circular, yellowish-brown in very young lesions, but quickly becoming orange to reddish-brown to black, becoming darker in the central region, hologenous, sometimes rolling or crinkling the leaves and shoots, the surrounding leaf tissue hardly affected, containing a large number of conidiomata, composed of an upper layer of plant whose cells are filled with bright orange-brown material, an intermediate layer of almost completely occluded angular to vertically elongated fungal cells, and the lower layer similar to the upper one. Conidiomata sphaerical, epigenous or hologenous, the ostiole epigenous, inconspicuous, slightly papillate or apapillate. Conidiomatal wall poorly developed, not clearly distinguishable from the stromatal tissue or composed of a narrow layer of small hyaline thick-walled textura angularis. Conidiogenous cells cylindrical but gradually tapering towards the upper region, which is slightly irregular in appearance due to successive conidial scars, usually proliferating sympodially, developing over the entire inner surface of the wall, arising as lateral or terminal branches from short relatively undifferentiated conidiophores. Conidia the lower part very narrowly lanceolate to fusiform, the upper part filiform, sigmoidally curved, the base truncate, hyaline, aseptate, apparently smooth-walled. Sexual morph: Ascostromata irregularlyshaped, usually roughly circular, strongly raising the adaxial surface of the leaf, flat or slightly concave on the abaxial surface, hologenous, reddish-brown to black, sometimes faintly verrucose, the ostioles sometimes inconspicuous but appearing as small black dots on paler stromata, often somewhat sunken, composed of pigmented outer layers and a hyaline inner layer containing the ascomata. Ascomata sphaerical. Paraphyses rather sparse, gradually tapering towards the apex, very thin-walled, strongly inflated between the septa. Asci 8-spored, unitunicate, clavate, longpedicellate, thin-walled at all stages, the apex obtuse, with an apical ring. Ascospores biseriate, 
cylindrical to ellipsoidal, occasionally obovoid, occasionally slightly curved (fabiform), hyaline, aseptate, thin- and smooth-walled, without a gelatinous sheath.

Type species - Polystigma rubrum (Pers.) DC., in de Candolle \& Lamarck, Fl. franç., Edn 3 (Paris) 5/6: 164 (1815)

Polystigma rubrum (Pers.) DC., in de Candolle \& Lamarck, Fl. franç., Edn 3 (Paris) 5/6: 164 (1815)

Fig. 5

Facesoffungi number: FoF02910

Reference specimen designated here: MFLU 15-3091

Parasitic on Prunus spp. Leaf spots developing on living leaves, scattered, irregular, swollen, orange to red, bordered by apparently healthy leaf tissue. Asexual morph: Conidial stromata 10-25 mm diam., irregularly-shaped, but usually roughly circular, orangish-brown in very young lesions, but quickly becoming orange to reddish-brown, becoming darker in the central region, locally hologenous (developing within and throughout the leaf tissue), bordered by apparently healthy leaf tissue, with number of conidiomata. Stromatal tissues composed of upper and lower layers of plant tissue 35-50 $\mu \mathrm{m}$ thick whose cells are filled with shiny orange-brown material, and an intermediate layer $250-540 \mu \mathrm{m}$ thick of almost completely occluded angular to vertically elongated fungal cells. Conidiomata 160-280 $\mu \mathrm{m}$ diam., roughly sphaerical. Ostiole inconspicuous. Conidiomatal wall poorly-developed, not clearly distinguishable from the stromatal tissue. Conidiogenous cells developing over the entire inner surface of the wall, often laterally from sequential cells of short conidiophores to 8-12 $\mu \mathrm{m}$ long and 1-2 $\mu \mathrm{m}$ wide; derived from a thin layer of textura angularis with hyaline thin-walled cells. Conidiogenous cells $10-30 \times 1-3.3(\bar{x}=25 \times 2.3 \mu \mathrm{m}, \mathrm{n}=20) \mu \mathrm{m}$, at first usually cylindrical but gradually tapering towards apex, which is slightly irregular in appearance due to successive conidial scars, usually proliferating sympodially. Conidia $20-48 \times$ $0.5-0.75(\bar{x}=35 \times 0.6 \mu \mathrm{m}, \mathrm{n}=20) \mu \mathrm{m}$, the lower part very narrowly lanceolate to fusiform, the upper part filiform, sigmoidally curved to hooked, the base \pm truncate, hyaline, aseptate, apparently smooth-walled. Sexual morph: Not observed.

Material examined - RUSSIA, Rostov Region, Shakhty city, Smagin urban microdistrict, abandoned dacha co-operative, allotment garden, on Prunus cerasifera, 20 Sept. 2015, T. Bulgakov T 0950 (MFLU 15-3091 reference specimen designated here).

Note - Polystigma rubrum, which is common on Prunus spp., has been reported mostly from Prunus cerasifera, Pr. domestica, Pr. domestica subsp. Insititia (syn. Pr. institia), Prunus spinosa and Pr.stepposa (syn. Pr. spinosa ssp. dasyphylla). Records on Pr. salicina have not been verified, and may refer to sub sp. ussuriense (Cannon 1996). This species has a wide distribution throughout the world with abundant collections reported from UK. The typification of Po. rubrum accompanies problems if application of the name is to continue with current practice because typification of Po. rubrum, introduced by Persoon (Cannon 1996), remains controversial. Cannon (1996) discussed that there are only two collections identified as Xyloma rubrum (basionym of Po. rubrum) in Persoon's herbarium in L (Nationaal Herbarium Nederland), neither being definite type material as poor collection data are availabe. L 910263-760 contains two portions of leaves, comprising developing ascomata of Po. rubrum. It is inscribed 'Hb. Pers. ded. Letellier' and (in a different hand) 'Dothidea rubra Fr.'). The material is in poor condition, and its identity is problematic. L 910263-779 contains several leaves with well-developed stromata, but the host is given as Prunus padus and two subsequent annotations re-identify the collection as Polystigma fulvum. Clearly, neither of these collections is suitable either as a lectotype or a neotype of Polystigma rubrum (Cannon 1996). Characteristics of the asexual morph of our isolate is similar with the protologue of Polystigma rubrum (Pers.) DC., in de Candolle \& Lamarck (Clements \& Shear 1931) (Fig. 5). With strong morphological and phylogenetic support we designate this specimen (MFLU 15-3091) as a reference specimen for Po. rubrum (sensu Ariyawansa et al. 2014) with the objective of providing the availability of a reliable herbarium material in good condition and corresponding molecular data for future studies. 


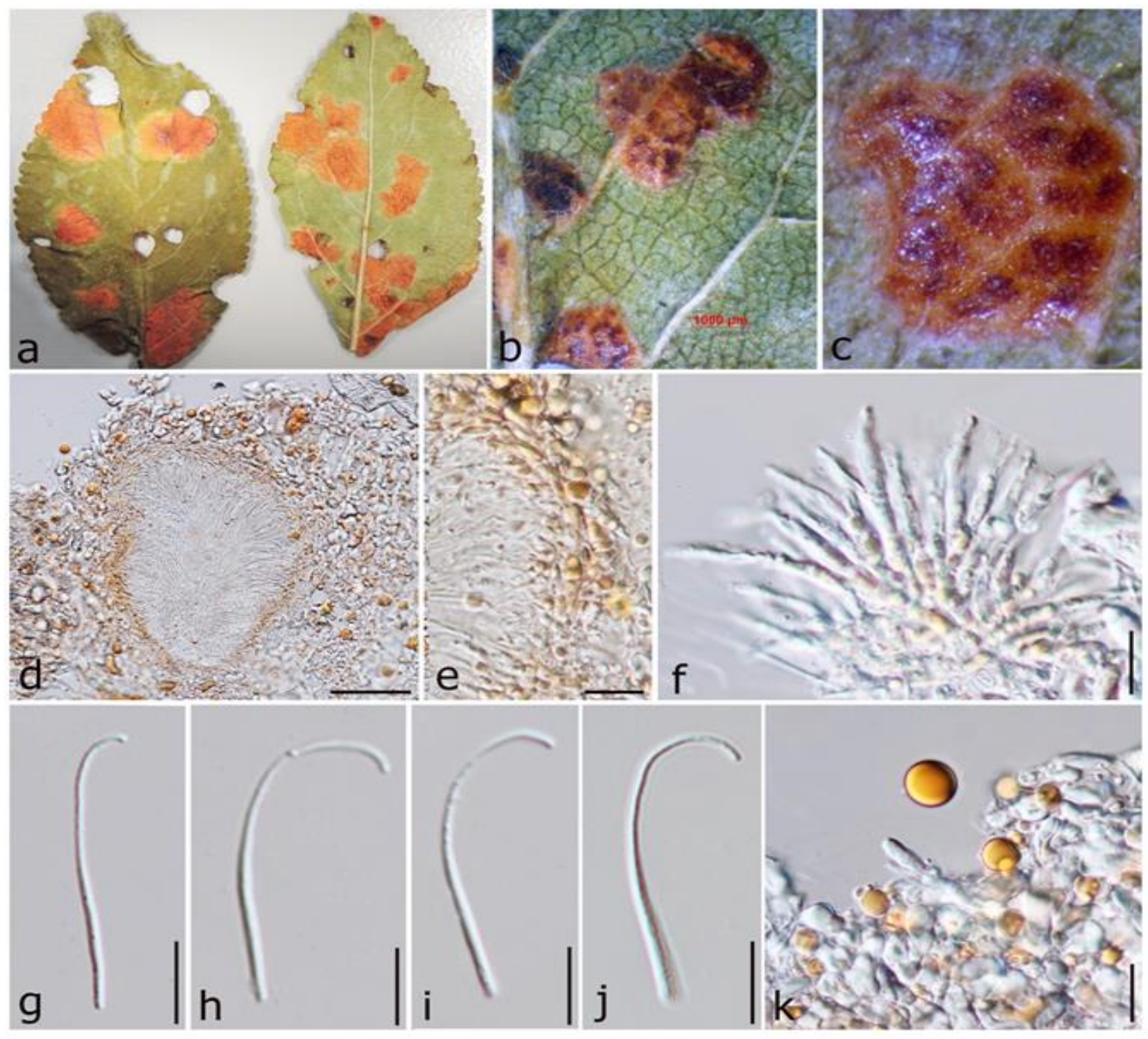

Figure 5 - Polystigma rubrum (MFLU15-3091 reference specimen) a. Swollen, red/orange/brown leaf spots on Prunus cerasifera (Rosaceae). b,c. Close ups of leaf spots on host. d. Section through pycnidial conidioma. e. Conidiomatal wall. f. Conidiogenous cells. g-j. Hooked conidia. k. Red/orange pigments in conidiomatal wall. Scale bars: $b=1000 \mu \mathrm{m}, \mathrm{d}=50 \mu \mathrm{m}, \mathrm{e}=20 \mu \mathrm{m}, \mathrm{f}-\mathrm{k}=$ $10 \mu \mathrm{m}$.

\section{Discussion}

Tar spot diseased specimens from various hosts were subjected to morpho-phylogenetic study and the family Phyllachoraceae re-appraised with combined LSU, SSU and ITS sequence data. Three novel species, Phyllchora chloridis, P. cynodonticola and P. panicicola, grouped in family Phyllachoraceae within the order Phyllachorales in a clade with Phyllachora species. Phyllachora chloridis, $P$. cynodonticola and $P$. panicicola bear morphological similarities with genus Phyllachora. Hence, we introduced them as new species. In addition, the type of $P$. graminis can be easily recognized and differentiated form $P$. chloridis, $P$. cynodonticola and $P$. panicicola by the presence of amphigenous pseudostromata that grows across the entire section of the leaf, occupying the epidermal tissue on both sides of the leaf, with broadly clavate lightly pitted ascospores formed within fusoid asci. The representatives of the type species ( . graminis) nested within this clade A, but did not group together (Fig. 1). Sequences generated from 101486 (isolated form Poaceae sp. in Brazil), MM-166 and DAOM 240981 clustered together, while RoKi3084 and UME 31349 formed a separate lineage. Strain TH544 was located sister to the strains of our novel species $P$. chloridis. 
However, there are no sequences generated from any type specimens of $P$. graminis. Therefore, it is necessary to obtain sequence data from a specimen of $P$. graminis to determine Phyllachora sensu stricto. Phyllachora furnasensis has fusoid-clavate asci with fusiform ascospores tapering towards the thick-walled apices, a characteristic that differentiates it from the novel species within this clade (Santos et al. 2016), which have fusiform to oval ascospores with a mucilaginous sheath. Phyllachora ermidensis can be clearly recognized as a different species from the species introduced in the present study as they lack a mucilaginous sheath around the ascospores. Santos et al. (2016) showed that Phyllachora qualeae which is a parasite on Qualea multiflora (Vochysiaceae) is sister to $P$. graminis (UB21307), but distant from most of the Phyllachora representatives. In our analysis, it is placed within family Phyllachoraceae. However only short ITS sequence data is available for $P$. qualeae strains hence, it is worth to retreat this genus with the multi-gene analyses including probably SSU and LSU data and a greater taxon sampling. Polystigma sp. (MM163) reported from Paspalum sp. (Poaceae) by Mardones et al. (2017) also clustered with Phyllachora species and there are no records to compare the morphology. Therefore, we included it as a phyllachora-like species in our phylogram. All Phyllachora species within this group has been reported from species of Poaceae and are host-specific. Two Phyllachora strains (MM-128 and MM-139) obtained from Bamboo is phylogenetically apart from Phyllachora species and are sistes taxa to Camarotella spp. within Phyllachoraceae. As there are no recods of morphology, we kept them as Phyllachora-like species during our analysis. It is worth to reconsider their morphology further. They all can be well distinguished as distinct species according to the phylogenetic analysis of combined LSU, SSU and ITS data.

Phyllachora representatives with subcuticular to intra-epidermal pseudostromata without a deep penetration into the palisade parenchyma are grouped within the order Phyllachorales as a basal clade to most of Phyllachoraceae species including the type refs. Characteristics confined to clade B have been well described by Santos et al. (2016). Three well-supported sub-clades were shown within this clade, with two of them comprising species from hosts belonging to the genus Myrcia. The other subclade comprises N. subcircinans, a parasite on Psidium species. Neophyllachora subcircinans comprises obclavate asci with oblong, short-ellipsoidal to subglobose ascospores, whereas in $N$. cerradensis, ascospores are ellipsoidal and guttulate. Neophyllachora myrciariae forms ascospores similar to those of $N$. cerradensis, but also forms fusoid-clavate phialidic conidia. Neophyllachora myrciae produces lunate ascospores inside clavate asci. Apart from these three groups, an additional species with sublunate to fusoid ascospores is located within this clade, $N$. trucantispora, as a basal species to the $N$. myrciae subclade. These observations are well-supported by the studies of Santos et al. (2016). Based on both morphological and phylogenetic evidence, we introduce a novel genus, Neophyllachora within Phyllachoraceae, to accommodate these taxa. Species of this genus are only found from hosts in the family Myrtaceae. However, most species in this genus have only short ITS sequence data therefore it is recommended to do further analysis with LSU and SSU data. Phyllachora sp. (RMB1061) associated with Panicum maximum formed a distinct lineage basal to Neophyllachora species. There are no morphological records of this species to compare and accomodate in the novel genus.

In a recent study on Polystigma by Habibi et al. (2015) Po. amygdalinumis, which was previously placed in Phyllachorales (subclass Sordariomycetidae) did not group in Phyllachorales but within Xylariales. Classification using only few taxonomic characters easily creates polyphyletic taxa that superficially resemble each other (Hausner et al. 1993, Spatafora \& Blackwell 1994). Mardones et al. (2017) included Polystigma amygdalinum on Prunus dulcis, Po. pusillum on Andira inermis and Polystigma sp. on Paspalum sp in their analyses; Polystigma amygdalinum, did not group among phyllachoraceous fungi but with Trichosphaeriales and Xylariales in the subclass Xylariomycetidae. Polystigma pusillum and Polystigma sp. cluster with Phyllachora species, but not as closely related species in our analysis. Cannon (1991) reported that Polystigma pusillum is similar to the genus Physalospora (Hyponectriaceae) mainly based on similar microscopic features of the two genera. Moreover, its phylogenetic placement within the order is still uncertain. However, based on our results, Po. amygdalinum and Po. rubrum (type 
species) which were isolated from Prunus spp. should in any case be placed in the order Xylariales. Hence, the family Polystigmataceae is re-instated with Po. rubrum as the type species. We could not observe the sexual morph of this species as they occur in spring and our collection was made in the summer. Morphological characters of family Polystigmataceae are provided considering all representatives of genus Polystigma and a reference specimen for Po. rubrum is provided.

Phyllachora species have previously been identified based on morphology and there are only a few sequences present in GenBank for comparison. Similarly, most of the species only have ITS data and even most of them are short sequences. This indicates the taxonomical instability still present within family Phyllachoraceae. The majority of species belonging to this family has been introduced based on the host on which they occur. Illustrations, original descriptions and molecular data are inadequate for the genus and hence, it is rather controversial when introducing novel species (Parbery 1967, 1971, Gabel et al. 1999, Habibi et al. 2015, Santos et al. 2016, Dayarathne et al. 2016). Furthermore, there are no adequate phylogenetic studies to confirm their host specificities or phylogenetic placements to resolve species confusions in naming. Therefore, it is necessary to synonymize, epitipify or logically remove the controversial older species names to facilitate proper identification of new species within the genus (Dayarathne et al. 2016).

\section{Acknowledgements}

We are grateful to the Thailand Research Fund (TRF) grant no RSA5980068 entitled Biodiversity, phylogeny and role of fungal endophytes on above parts of Rhizophora apiculata and Nypa fruticans and National Research Council of Thailand (NRCT) for a grant entitled Diseases of mangrove trees and maintenance of good forestry practice (Grant number: 60201000201). Kevin D. Hyde thanks the Chinese Academy of Sciences, project number 2013T2S0030, for the award of Visiting Professorship for Senior International Scientists at Kunming Institute of Botany. We also acknowledge Mae Fah Luang University and Kunming Institute of Botany for providing laboratory facilities to carry out taxonomic and molecular work. Monika Dayarathne offers her deepest gratitude to Chinthani Senanayake, Dhanushka Wanasinghe, Anupama Daranagama, Samantha Karunarathne and Rungtiwa Phookamsak for their helpful comments and advices. Eric McKenzie and Kevin D. Hyde are visiting professors at Chiang Mai University, Chiang Mai, Thailand.

\section{References}

Ariyawansa HA, Hawksworth DL, Hyde KD, Jones EBG et al. 2014 - Epitypification and neotypification-guidelines with appropriate and inappropriate examples. Fungal Diversity 69, 57-91.

Barr ME. - 1990 Prodromus to nonlichenized. Pyrenomycetous members of class Hymenoascomycetes. Mycotaxon 39, 98-100.

Barr ME. 1976a - Buergenerula and the Physosporellaceae. Mycologia 68, 611-621.

Barr ME. 1976b - Perspectives in the Ascomycotina. Mem N Y Bot Gard 28, 1-8.

Barr ME. 1983 - The ascomycete connection. Mycologia 75, 1-13.

Cannon PF. 1988 - Proposal to merge the Phyllachorales with the Diaporthales, with a new family structure. Systema Ascomycetum 7, 23-43.

Cannon PF. 1991 - A revision of Phyllachora and some similar genera on the host family Leguminosae. Mycological Papers 163, 302.

Cannon PF. 1996 - Systematics and diversity of the Phyllachoraceae associated with Rosaceae, with a monograph of Polystigma. Mycological Research 100, 1409-1927.

Cannon PF. 1997 - Strategies for rapid assessment of fungal diversity. Biodiversity and Conservation 6, 669-680.

Chadefaud M. 1960 - Les végétaux non vasculaires (Cryptogamie). In: Chadefaud M. Emberger L (eds) Traité de botanique systématique. Tome I, Masson et Cie, Paris, pp 613-616.

Clements FE, Shear C. 1931 - The Genera of Fungi. New York: H.W. Wilson. 
Dayarathne MC, Boonmee S, Braun U, Crous PW et al. 2016 - Taxonomic utility of old names in current fungal classification and nomenclature: Conflicts, Confusion \& Clarifications. Mycosphere 7, 1622-1648.

Eriksson OE, Hawksworth DL. 1993 - Outline of the ascomycetes 1993. Systema Ascomycetum $12,51-257$.

Eriksson OE. 1967 - On graminicolous pyrenomycetes from Fennoscandia 3. Amerosporous and didymosporous species. Archiv für Botanik ser 2, 441-466.

Eriksson OE. 1982 Outline of the Ascomycetes -1982. Mycotaxon 15, 203-248.

Farr DF, Rossman AY. 2016 - Fungal databases, systematic mycology and microbiology laboratory, ARS, USDA. Retrieved January 11, 2015, from http://nt.arsgrin.gov/fungaldatabases/.

Fuckel L. 1867 - Fungi Rhenani Exsiccati Cent. XIX-XXI. 19-21, 1801-2100.

Gabel AC, Gabel ML, Cabral D. 1999 - New records of Phyllachora on Poaceae from Argentina. Mycotaxon 70, 477-488.

Habibi A, Banihashemi Z, Mostowfizadeh-Ghalamfarsa R. 2015 - Phylogenetic analysis of Polystigma and its relationship to Phyllachorales. Phytopathologia Mediterranea 54, 45-54.

Hall TA. 1999 - BioEdit: a user-friendly biological sequence alignment editor and analysis program for Windows 95/98/NT. Nucleic Acids Symposium Series 41, 95-98.

Hanlin RT, Tortolero O. 1991 - Icones ascomycetum Venezuelae: Phyllachora fusicarpa. Mycotaxon 41, 19-26.

Hausner G, Reid J, Klassen, GR. 1993 - On the phylogeny of Ophiostoma, Ceratocystis s.s., and Microascus, and relationships within Ophiostoma based on partial ribosomal DNA sequences Canadian Journal of Botany 71, 1249-1265.

Hawksworth DL, Kirk PM, Sutton BC, Pegler DN. 1995 - Dictionary of the Fungi. $8^{\text {th }}$ Edn. 616.

Hawksworth DL, Sutton BC, Ainsworth GC. (eds). 1983 - Ainsworth \& Bisby's Dictionary of the Fungi, $7^{\text {th }}$ edn. CABI, Kew.

Hawksworth DL. 1985 - Problems and prospects in the systematics of the Ascomycotina. Proceedings of the Indian Academy of Science 94, 319-339.

Hongsanan S, Maharachchikumbura SS, Hyde KD, Samarakoon MC et al. 2017 - An updated phylogeny of Sordariomycetes based on phylogenetic and molecular clock evidence. Fungal Diversity 84, 25-41.

Horst RK. 1990 - Westcott's plant disease handbook, $5^{\text {th }}$ edn. AVI Book, USA.

Hyde KD, Cannon PF. 1999 - Fungi causing tar spots on palmae. Mycological Papers 175, 1-114.

Index Fungorum, (2016 - http://www.indexfungorum.org/Names/Names.asp. (accessed: October 2016).

Jayasiri SC, Hyde KD, Ariyawansa HA, Bhat J et al. 2015 - The Faces of Fungi database: fungal names linked with morphology, phylogeny and human impacts. Fungal Diversity 74, 3-18.

Jeewon R, Hyde KD 2016 - Establishing species boundaries and new taxa among fungi: recommendations to resolve taxonomic ambiguities. Mycosphere 7 (11), 1669-1677.

Locquin M. 1984 - Mycologie Générale et Structurale. Masson, Paris.

Lost and Found Fungi project website, 2015 - http://fungi.myspecies.info/content/lost-found-fungiproject (accessed: October 2016).

Luttrell ES. 1951 - Taxonomy of the Pyrenomycetes. Curators Univ Mo 24, 1-3.

Maharachchikumbura SSN, Hyde KD, Jones EBG, McKenzie EHC et al. 2016 - Families of Sordariomycetes. Fungal Diversity 79, 1-317.

Mardones M, Trampe-Jaschik T, Oster S, Elliott M, Urbina H, Schmitt I, Piepenbring M. 2017 Phylogeny of the order Phyllachorales (Ascomycota, Sordariomycetes): among and within order relationships based on five molecular loci. Persoonia 39, 74-90.

Miller JH. 1949 - A revision of the classification of the Ascomycetes with special emphasis on the Pyrenomycetes. Mycologia 41, 99-127.

Muller E, von Arx JA. 1962 - Die Gattungen der didymosporen Pyrenomyceten. Beitr Kryptogamenflora Schweiz 11, 1-922. 
Nannfeldt JA. 1932 - Studien über die Morphologie und Systematikder nicht-lichenisierten, inoperculaten Discomyceten. Nova Acta R Soc Sci Upsaliensis Ser 6(8), 1-368.

Parbery DG. 1967 - Studies on graminicolous species of Phyllachora-like. in fckl. v. A taxonomic monograph. Australian Journal of Botany 15, 271-375.

Parbery DG. 1971 - Studies on graminicolous species of Phyllachora Nke. in Fckl. Australian Journal of Botany 19, 207-235.

Pearce CA, Hyde KD. 1993 - The genus Phyllachora from Australia. Observations on P. bella from Syzygium paniculatum and P. melaspilea from Scolopia braunii. Mycological Research 97, 1437-1440.

Pearce CA, Hyde KD. 2001 - Two new genera in the Phyllachoraceae: Sphaerodothella to accommodate Sphaerodothis danthoniae, and Parberya gen nov. Fungal Diversity 6, 83-97.

Pearce CA, Reddell P, Hyde KD. 1999 - A revision of Phyllachora (Ascomycotina) on hosts in the angiosperm family Asclepiadaceae, including P. gloriana sp. nov., on Tylophora benthamii from Australia. Fungal Diversity 3, 123-138.

Pearce CA, Reddell P, Hyde KD. 2000 - A member of the Phyllachora shiraiana complex (Ascomycota) on Bambusa arnhemica: a new record for Australia. Australasian Plant Pathology 29, 205-210.

Pearce CA, Reddell P, Hyde KD. 2001 - Revision of the Phyllachoraceae (Ascomycota) on hosts in the Angiosperm family, Proteaceae. Australian Systematic Botany 14(2), 283-328.

Santos MD, Fonseca-Boiteux ME, Boiteux LS, Câmara PE, Dianese JC. 2016 - ITS-phylogeny and taxonomy of Phyllachora species on native Myrtacae from the Brazilian Cerrado. Mycologia (in press) doi:10.3852/16-025.

Seaver FJ. 1928 - Studies in tropical Ascomycetes-V. Species of Phyllachora. Mycologia 20, 214 225.

Silvestro D, Michalak I. 2011 - raxmlGUI: a graphical front-end for RAxML. Organisms Diversity \& Evolution 12, 335-337.

Sivanesan A, Shivas RG. 2002 - New species from each of the pyrenomycete genera Hyponectria, Physalospora and Trichosphaeria from Queensland, Australia. Fungal Diversity 9, 169-174.

Spatafora JW, Blackwell M. 1994 - The polyphyletic origins of ophiostomatoid fungi. Mycological Research 98, 1-9.

Subileau C, Renard L, Dennetiere B. 1993 - Phyllachora torrendiella (Batista) comb. nov., responsable de la maladie verruqueuse du cocotier. Mycotaxon 49, 175-185.

Tamakaew N, Maharachchikumbura SSN, Hyde KD, Cheewangkoon R. 2017 - Tar spot fungi from Thailand. Mycosphere 8, 1054-1058.

Tamura K, Peterson D, Peterson N, Stecher G et al. 2011 - MEGA5: molecular evolutionary genetics analysis using maximum likelihood, evolutionary distance and maximum parsimony methods. Molecular Biology and Evolution 28, 2731- 2739.

Theissen F, Sydow H. 1915 - Die Dothideales. Annales Mycologici 13, 147-746.

Viégas AP. 1944 - Alguns fungos do Brasil. II. Ascomycetos. Bragantia 41-492.

Vilgalys R, Hester M. 1990 - Rapid genetic identification and mapping of enzymatically amplified ribosomal DNA from several Cryptococcus species. Journal of Bacteriology 172, 4238-4246.

Wehmeyer LE. 1975 - The pyrenomycetous fungi. Matsushima Mycological Memoirs 6, 1-250.

White T, Bruns T, Lee S, Taylor J. 1990 - Amplification and direct sequencing of fungal ribosomal RNA genes for phylogenetics. PCR protocols a guide to methods and applications 18, 315322.

Wijayawardene NN, Hyde KD, Rajeshkumar KC. et al. 2017 - Notes for genera: Ascomycota. Fungal Diversity 86(1), 1-594. 